\title{
The enriched Variscan lithosphere of NE Iberia: data from post- collisional Permian calc-alkaline lamprophyre dykes of Les Guilleries
}

\author{
Esteban Mellado $^{1} \quad$ Mercè Corbella $^{1} \quad$ Didac Navarro-Ciurana $^{1} \quad$ Andrew Kylander-Clark $^{2}$ \\ 'Departament de Geologia, Facultat de Ciències, Universitat Autònoma de Barcelona \\ Carrer de la Vall Moronta s/n, 08193 Bellaterra, Barcelona, Spain. \\ Telephone: +34677086033, ORCID: 0000-0002-4818-3534. \\ Mellado E-mail: esteban.mellado@e-campus.uab.cat \\ 2LASS Facility, University of California \\ Santa Barbara, CA 93106, USA
}

\begin{abstract}
Post-collisional mafic dykes crosscut the Paleozoic metamorphic basement and late-Variscan plutons in Les Guilleries massif (Catalan Coastal Ranges, NE Iberia). The predominance of mafic phenocrysts, porphyritic texture, abundant amphibole, high $\mathrm{MgO}$ and volatile content, together with crustal-like trace-element patterns indicate that the dykes correspond to calc-alkaline lamprophyres, mainly spessartites. Their enrichment in LILE, HFSE and REE and initial $\mathrm{Sr}-\mathrm{Nd}$ isotopic compositions $\left({ }^{87} \mathrm{Sr}^{86} \mathrm{Sr}_{\mathrm{i}}\right.$ between 0.70851 and $0.71127, \varepsilon \mathrm{Nd}_{\mathrm{i}}$ between -5.23 and -4.63$)$ are consistent with an enriched subcontinental lithospheric mantle source. U-Pb ages of matrix titanite crystals yield concordia ages of $262 \pm 7 \mathrm{Ma}$, congruent with crosscutting relationships. Post-magmatic processes are evidenced by intense chloritization and albitization of the lamprophyres, together with systematic variations of $\mathrm{Na}_{2} \mathrm{O}$ vs $\mathrm{SiO}_{2}$, $\mathrm{K}_{2} \mathrm{O}, \mathrm{CaO}, \mathrm{Ba}, \mathrm{Rb}, \mathrm{Cs}, \mathrm{Pb}, \mathrm{Sr}, \mathrm{Tl}$, and $\mathrm{Zn}$, and possibly the removal of $\mathrm{F}$ The geochemical and geochronological data support an orogenic geochemical affinity, in accordance with the transitional tectonic regime between Variscan compression/transpression and post-collisional transtension/extension, related to the fragmentation of Pangea and thinning of the lithosphere. The lamprophyre dykes studied could represent the youngest pulse of Variscan orogenic magmatism and, therefore, mark its end in NE Iberia before the onset of the generalized Triassic extension.
\end{abstract}

KEYWORDS

Calc-alkaline lamprophyre. Post-collisional dykes. Sr-Nd isotopes. Les Guilleries Massif. Catalan Coastal Ranges. Variscan Orogeny.

\section{INTRODUCTION}

Dyke swarms hold one of the keys to understanding the plate tectonics as they provide information on the extensional processes occurring in the continental and oceanic lithosphere (Peng et al., 2016). Mafic dykes in particular are the primary channels of deep magma transport into the crust from a source area in the mantle; they can thus be used to assess the nature of their parental magmas, location of magma reservoirs, emplacement mechanisms and/or regional paleostress conditions and to reconstruct ancient continental palaeogeographic regimes (Srivastava et al., 2019).

In the Variscan Belt of Western Europe, mafic dyke swarms are essential constituents of the two main tectono- 
magmatic and sedimentary cycles defined for the postcollisional orogenic evolution (Cortesogno et al., 1998). The first cycle of Upper Carboniferous-Lower Permian age is ruled by an extensional, trans-tensional tectonic regime and is characterized by the calc-alkaline plutonic-volcanic magmatism and fluvio-lacustrine sedimentation. Dyke emplacement in the first cycle occurred diachronically in the Pyrenees, Iberian Ranges, Catalan Coastal Ranges (CCR) and Sardinia, and at different crustal levels (Lago et al., 2004; Perini et al., 2004; Ronca et al., 1999; Ubide et al., 2010; respectively). The second cycle is characterized by a plutonic-volcanic magmatism of alkaline geochemical signature associated with continental and shallow-marine sedimentation, generally developed from late Permian to early Triassic in south-western Europe, but was active since early Permian in some places (Cortesogno et al., 1998). It marks an extensional event disconnected from the collapse of the Variscan belt, and likely related with the postVariscan global re-organization of plates that would lead to the neo-Tethyan rifting in late Triassic times (Bonin, 1987; Orejana et al., 2008; Wilson et al., 2004).

The calc-alkaline mafic dyke swarms of the first cycle include, in some locations, potassium-rich varieties, such as lamproites, and calc-alkaline lamprophyres (spessartites, vosgesites, kersantites and minettes), that suggest the Variscan Subcontinental Lithospheric Mantle (SCLM) sources contained enriched domains in LILE (Large Ion Lithophile Elements: Ba, K, Rb, Sr, Th, U and Pb), HFSE (High Field Strength Elements: Hf, Nb, Ta, Ti, Zr and P) and REE (Rare Earth Elements), with high ${ }^{87} \mathrm{Sr} /{ }^{86} \mathrm{Sr}_{\mathrm{i}}$ and low $\varepsilon \mathrm{Nd}_{\mathrm{i}}$ (Perini et al., 2004; Seifert, 2008; Soder, 2017). The general consensus is that these enriched domains are formed by metasomatism of the SCLM in suprasubduction zones when silica-rich, carbonatite-rich and/or asthenospheric melts penetrate mantle peridotite as vein networks (Foley, 1992; Prelević et al., 2004; Seifert, 2008; Soder, 2017). Then, when the enriched mantle domains are affected by low degree melting, potassium-rich mafic magmas with a hybrid crustal and mantle signature may form; this magma can differentiate during ascent and may emplace at different crustal levels (Awdankiewicz, 2007; Elter et al., 2004; Prelević et al., 2004; Soder, 2017).

Alkaline mafic dykes of the second cycle also include potassium rich varieties such as camptonites, but they have a distinctive Oceanic Island Basalt (OIB) trace-element character with enrichments in LILE, HFSE and Light Rare Earth Elements (LREE), positive $\mathrm{Nb}-\mathrm{Ta}$ and $\mathrm{Ti}$ anomalies, low ${ }^{87} \mathrm{Sr} /{ }^{86} \mathrm{Sr}_{\mathrm{i}}$ and high $\varepsilon \mathrm{Nd}_{\mathrm{i}}$. This suggests an anorogenic nature of the magmas with no involvement of crustal and/ or subduction-related components (Orejana et al., 2008; Scarrow et al., 2009).

The Catalan Coastal Ranges (CCR), which conform the north-easternmost Variscan domain of the Iberian
Peninsula, contain different sets of lamprophyric dyke swarms. In the locality of Aiguablava, at Costa Brava, dykes with a calc-alkaline geochemical signature appear crosscut by others of alkaline affinity (Enrique, 2009; Ubide et al., 2010). The former (mainly spessartites) intrude a ca. 288Ma leucogranite and have been interpreted to be of Permian age (Enrique, 2009; Losantos, 2000). Structural analyses have shown that these dykes are oriented WNWESE and intruded along a preexisting joint network in lateVariscan batholiths during a post-collisional extensional/ transtensional tectonic regime (Martínez-Poza et al., 2014). The second type of lamprophyres correspond to camptonites, which have ${ }^{40} \mathrm{Ar} /{ }^{39} \mathrm{Ar}$ ages of ca. $79.0 \pm 0.5 \mathrm{Ma}$, unrelated to the Variscan orogeny (Ubide, 2013). This author interpreted the alkaline lamprophyres of CCR to represent the final stage of a series of alkaline magmatic pulses in NE Iberia that could have started during Triassic times, and lasted until the beginning of the Alpine orogeny, in relation with the continental rift setting developed in SW Europe during that period.

Vertical lamprophyric dykes also occur in Les Guilleries Massif, in the West-Central part of the CCR (about $50 \mathrm{~km}$ west of Aiguablava), cutting metamorphic Paleozoic rocks (Fig. 1) and Variscan granitoids. Although they have been observed by many geologists, they have not been characterized yet. This study presents the petrography, geochemistry and geochronology of Les Guilleries Lamprophyre (LGL) dykes in order to evaluate their mantle source characteristics, melting conditions, time of emplacement, post-magmatic hydrothermal events and regional correlations. To facilitate correlations, geochemical data of the main Variscan magmatic occurrences of NE Iberia and nearby Paleozoic massifs are compiled and plotted alongside those of Les Guilleries.

\section{GEOLOGICAL SETTING}

Les Guilleries Massif, located in the north-western part of the CCR (Fig. 1A), mainly consists of CambroOrdovician metasedimentary units and orthogneisses cut by Variscan syn- to post-collisional intrusions (Durán, 1985, 1990). The massif is composed of three blocks separated by NE-SW striking normal faults. The deeper and highergrade metamorphic block, the Osor block, outcrops in the southern part of the massif and contains sillimanitegrade metapelites with interlayered metapsammites, calc-silicates, amphibolites, and orthogneisses (Durán, 1985, 1990; Martínez et al., 2008; Reche and Martínez, 2002; Sebastian, et al., 1990). The Susqueda block is the intermediate one, which is composed of metapelites and metapsammites with quartzite layers and represents shallower levels of the crust, as the metamorphism reaches the andalusite-cordierite grade. The Osor and Susqueda 

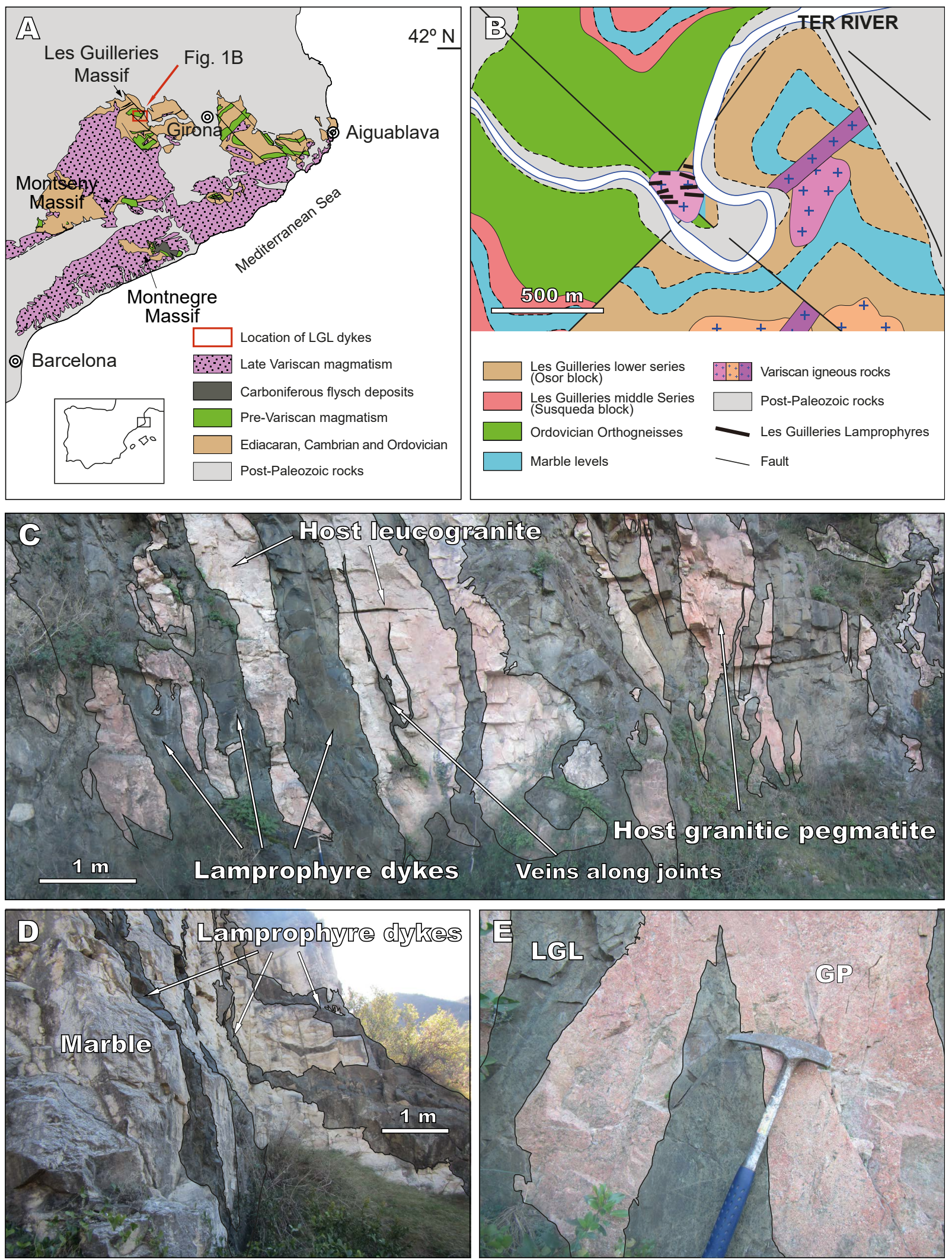

FIGURE 1. A) Location of les Guilleries Massif and Les Guilleries Lamprophyre (LGL) dykes within the Catalan Coastal Ranges. B) Detailed geological map of the study area and location of les Guilleries Lamprophyre dykes. C) Photograph of a lamprophyre dyke swarm cross-cutting Variscan leucogranites and granitic pegmatites. D) Photograph of lamprophyre dykes in a host marble. E) Photograph of lamprophyres (LGL) in a Variscan Granitic Pegmatite (GP) host. 
blocks contain sill-like bodies of orthogneisses that record essentially continuous magmatic activity beginning at the Cambro-Ordovician boundary $(488 \pm 3 \mathrm{Ma})$ and reaching a peak of intrusions volume during the late Ordovician (462 \pm 8 to $459 \pm 3 \mathrm{Ma}$; Martínez et al., 2011). The northern and uppermost Sant Martí block is composed of Ordovician metavolcanic rocks interbedded with metagreywackes and

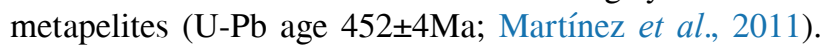
Some Silurian and Devonian volcanosedimentary rocks also crop out in the northern part, although the sequences appear incomplete due to faulting (Durán, 1990).

Several Variscan igneous rocks intruded the metasedimentary sequences of Les Guilleries Massif. The oldest Variscan intrusive forms the Susqueda complex, the largest basic massif of the CCR, which is composed of quartz diorites and diorites with calcalkaline geochemical affinity, together with hornblende gabbros and hornblendites (Enrique, 1990; Esteve et al., 2016). One syn-collision diorite sheet provided an U-Pb age of 323.6 $\pm 2.8 \mathrm{Ma}$ (Martínez et al., 2008), and most mafic intrusives are considered younger and post-tectonic (Esteve et al., 2018). The Susqueda complex induces granulite-grade contact metamorphism and silica depleted melting in the host Susqueda block metasediments (Riesco et al., 2004). Younger granites 305-299Ma old (U-Pb zircon ages; Martínez et al., 2008) are abundant in the Osor block. Unpublished U-Pb Sensitive High MassResolution Ion Microprobe (SHRIMP) ages of $284 \pm 3 \mathrm{Ma}$ have been found for post-collisional porphyritic granitoids (FJ. Martínez personal communication), which agree with the age of similar mafic and felsic plutonic bodies in the nearby Montnegre Massif, that yield ${ }^{40} \mathrm{Ar} /{ }^{39} \mathrm{Ar}$ ages between ca. 291 and 285Ma (Solé et al., 2002). Ultrabasicbasic to intermediate rocks also appear associated with late-Variscan calc-alkaline granites in the Montnegre Massif, showing mineralogical and geochemical characteristics typical of appinite suites, with cumulate hornblendites and gabbros crystalized from K-rich and fluid-rich magmas and a complex mingled zone between diorites and biotite granodiorites (Butjosa et al., 2013; Galán et al., 2017).

Several types of ore mineralizations have been found in Les Guilleries (Ayora, 1990). Epigenetic mineralizations, mainly skarns $(\mathrm{Cu}, \mathrm{Fe}, \mathrm{Zn}, \mathrm{Pb})$ and veins $(\mathrm{F}, \mathrm{Ba}, \mathrm{Zn}, \mathrm{Pb})$, seem to be related to hydrothermal fluid circulation induced by the post-metamorphic granitic intrusions (Ayora, 1990). The most important deposit occurs in the Osor block and consists of fluorite-barite veins with sphalerite and galena crosscutting Variscan porphyritic granites and metapelites. These veins show different stages of recrystallization that have been attributed to Variscan movements and subsequent rejuvenation during the Alpine orogeny (Campá-Viñeta and Montoriol-Pous, 1974).
To date, Permain basins haven't been observed in Les Guilleries Massif. The area is thus interpreted as a topographic high since early Permian and affected by the Permo-Triassic erosional paleosurface, adjacent to pullapart basins developed in dextral transtensional settings (Innocent et al., 1994; Lago et al., 2004). Some of the nearest Permian records are found in the Eastern Pyrenees, 90km to the NE (Serra del Cadí; Innocent et al., 1994) and in the Iberian Ranges, $300 \mathrm{~km}$ to the SE. These Permian basins record several syn- and post-rift depositional cycles, with or without volcanism, and a marked transition from calc-alkaline volcanism in the early-mid Permian to alkaline volcanism in the late Permian (Arche and López-Gómez, 1996; Innocent et al., 1994).

\section{SAMPLING AND ANALYTICAL TECHNIQUES}

Seven lamprophyre dykes and their wall-rocks were sampled in order to cover the differences encountered in the field. Petrographic analysis and Scanning Electron Microscope (SEM) characterization were performed at the Geology Department and Serveis de Microscòpia of the Universitat Autònoma de Barcelona. The representative 13 samples were crushed and pulverized to $200 \mu \mathrm{m}$ and sent to ACTLABS, Ontario (Canada), for whole-rock geochemical analysis of 51 elements, including major, trace and rare earth elements. The analytical techniques used were lithium metaborate/tetraborate fusion with subsequent analysis by Ion Selective Electrode (ISE) for fluorine and Inductively Coupled Plasma Mass Spectrometry (ICP-MS) for the rest of the elements $\left(\mathrm{SiO}_{2}, \mathrm{TiO}_{2}, \mathrm{Al}_{2} \mathrm{O}_{3}, \mathrm{Fe}_{2} \mathrm{O}_{3}, \mathrm{MnO}, \mathrm{MgO}\right.$, $\mathrm{CaO}, \mathrm{Na}_{2} \mathrm{O}, \mathrm{K}_{2} \mathrm{O}, \mathrm{P}_{2} \mathrm{O}_{5}$, Li, Be, Sc, V, Cr, Co, Ni, Cu, Zn, Ga, $\mathrm{Ge}, \mathrm{Rb}, \mathrm{Sr}, \mathrm{Y}, \mathrm{Zr}, \mathrm{Nb}, \mathrm{Sn}, \mathrm{Cs}, \mathrm{Ba}, \mathrm{La}, \mathrm{Ce}, \mathrm{Pr}, \mathrm{Nd}, \mathrm{Sm}, \mathrm{Eu}$, Gd, Tb, Dy, Ho, Er, Tm, Yb, Lu, Hf, Ta, W, Tl, Pb, Th and $\mathrm{U})$. Detection limits and analytical errors are presented in Table 1.

$\mathrm{Sr}-\mathrm{Nd}$ isotopic analyses were carried out at the Geochronology Unit of Universidad Complutense de Madrid (UCM). For ${ }^{87} \mathrm{Sr} /{ }^{86} \mathrm{Sr}$, a mass spectrometer VG Sector-54® was used, following data acquisition method of dynamic multicollection during 10 blocks of 16 cycles each, with beam intensity of $3 \mathrm{~V}$. Isotopic standards used were NBS $987\left({ }^{87} \mathrm{Sr} /{ }^{86} \mathrm{Sr}=0.710248 \pm 0.000003\right.$, National Bureau of Standards Certificate of Analysis). For ${ }^{143} \mathrm{Nd} /{ }^{144} \mathrm{Nd}$ mass spectrometer TIMS-Phoenix ${ }^{\circledR}$ was used, following data acquisition method of dynamic multicollection during 160 cycles with beam intensity of $1 \mathrm{~V}$. Isotopic standard used was $\mathrm{JNd}_{\mathrm{i}-1}\left({ }^{143} \mathrm{Nd} /{ }^{144} \mathrm{Nd}=0.512115 \pm 0.000002\right.$; Tanaka et al., 2000). Analytical errors referred to two standard deviations are $0.01 \%$ for ${ }^{87} \mathrm{Sr} /{ }^{86} \mathrm{Sr}$ and $0.006 \%$ for ${ }^{143} \mathrm{Nd} /{ }^{144} \mathrm{Nd}$.

$\mathrm{U}-\mathrm{Pb}$ age measurements were conducted for titanite and allanite grains of samples from two dykes. Thin sections 
TABLE 1. Whole-rock major and trace element concentration of LGL dykes

\begin{tabular}{|c|c|c|c|c|c|c|c|c|c|c|c|c|c|c|c|}
\hline & Unit & $\mathrm{DL}$ & $\begin{array}{l}\text { Dyke } \\
1\end{array}$ & $\begin{array}{l}\text { Dyke } \\
2\end{array}$ & $\begin{array}{l}\text { Dyke } \\
3\end{array}$ & $\begin{array}{l}\text { Dyke } \\
4\end{array}$ & $\begin{array}{l}\text { Dyke } \\
5\end{array}$ & $\begin{array}{l}\text { Dyke } \\
6\end{array}$ & QMonz & Grd & GrPeg & LeuGr & LeuGr & LeuGr & LeuGr \\
\hline $\mathrm{SiO}_{2}$ & wt.\% & 0.01 & 49.82 & 51.19 & 51.78 & 53.53 & 51.85 & 50.49 & 70.67 & 67.45 & 74.99 & 70.95 & 71.67 & 68.32 & 66.81 \\
\hline $\mathrm{Al}_{2} \mathrm{O}_{3}$ & wt. \% & 0.01 & 16.46 & 15.24 & 16.44 & 15.75 & 16.17 & 15.53 & 14.94 & 16.14 & 13.99 & 14.96 & 14.73 & 15.36 & 15.84 \\
\hline $\mathrm{Fe}_{2} \mathrm{O}_{3}(\mathrm{~T})$ & wt. \% & 0.01 & 8.09 & 9.02 & 9.09 & 8.66 & 8.45 & 9.15 & 3.49 & 4.06 & 0.75 & 2.67 & 2.69 & 2.75 & 3.12 \\
\hline $\mathrm{MnO}$ & wt. \% & 0.001 & 0.188 & 0.165 & 0.169 & 0.193 & 0.141 & 0.134 & 0.169 & 0.15 & 0.046 & 0.046 & 0.052 & 0.052 & 0.056 \\
\hline $\mathrm{MgO}$ & wt.\% & 0.01 & 6.16 & 6.75 & 5.39 & 6.34 & 6.38 & 6.66 & 0.81 & 1.61 & 0.3 & 1.3 & 1.15 & 1.48 & 1.65 \\
\hline $\mathrm{CaO}$ & wt. \% & 0.01 & 6.42 & 5.72 & 5.65 & 3.61 & 6.35 & 6.56 & 2.31 & 2.51 & 0.63 & 1.03 & 0.81 & 0.99 & 1.06 \\
\hline $\mathrm{Na}_{2} \mathrm{O}$ & wt. \% & 0.01 & 2.47 & 3.13 & 3.71 & 4.33 & 2.77 & 2.46 & 3.49 & 4.12 & 4.65 & 4.05 & 4.34 & 4.4 & 4.93 \\
\hline $\mathrm{K}_{2} \mathrm{O}$ & wt. \% & 0.01 & 2.05 & 1.71 & 0.8 & 0.27 & 1.12 & 1.29 & 3.25 & 2.29 & 3.84 & 2.69 & 2.77 & 2.6 & 2.77 \\
\hline $\mathrm{TiO}_{2}$ & wt. $\%$ & 0.001 & 1.409 & 1.318 & 1.453 & 1.376 & 1.306 & 1.418 & 0.338 & 0.498 & 0.051 & 0.351 & 0.356 & 0.387 & 0.421 \\
\hline $\mathrm{P}_{2} \mathrm{O}_{5}$ & wt.\% & 0.01 & 0.37 & 0.39 & 0.4 & 0.37 & 0.34 & 0.42 & 0.11 & 0.15 & 0.22 & 0.11 & 0.16 & 0.14 & 0.17 \\
\hline LOI & wt. \% & & 5.29 & 4.08 & 4.66 & 5.01 & 4.36 & 5.88 & 0.83 & 1.61 & 0.79 & 1.75 & 1.72 & 2.05 & 1.95 \\
\hline Total & wt. \% & 0.01 & 98.72 & 98.72 & 99.56 & 99.44 & 99.23 & 100 & 100.4 & 100.6 & 100.3 & 99.9 & 100.4 & 98.54 & 98.77 \\
\hline$F$ & wt. \% & 0.01 & 0.08 & 0.06 & 0.06 & 0.07 & 0.03 & & & & & 0.02 & 0.02 & 0.03 & 0.03 \\
\hline Sc & ppm & 1 & 27 & 25 & 27 & 26 & 26 & 25 & 7 & 9 & 5 & 6 & 6 & 6 & 6 \\
\hline $\mathrm{Be}$ & ppm & 1 & 2 & 2 & 3 & 3 & 2 & 2 & 1 & 1 & 2 & 2 & 2 & 2 & 2 \\
\hline V & ppm & 5 & 176 & 161 & 173 & 148 & 167 & 175 & 29 & 48 & $<5$ & 26 & 28 & 29 & 37 \\
\hline $\mathrm{Cr}$ & ppm & 20 & 210 & 280 & 150 & 190 & 200 & 300 & 50 & 30 & $<20$ & $<20$ & $<20$ & $<20$ & $<20$ \\
\hline Co & ppm & 1 & 29 & 33 & 44 & 32 & 41 & 32 & 47 & 27 & 67 & 28 & 38 & 33 & 23 \\
\hline $\mathrm{Ni}$ & ppm & 20 & 80 & 100 & 50 & 70 & 80 & 110 & $<20$ & $<20$ & $<20$ & $<20$ & $<20$ & $<20$ & $<20$ \\
\hline $\mathrm{Cu}$ & ppm & 10 & $<10$ & 30 & 40 & $<10$ & 30 & 30 & 40 & 10 & 10 & $<10$ & $<10$ & $<10$ & $<10$ \\
\hline $\mathrm{Zn}$ & ppm & 30 & 130 & 130 & 170 & 230 & 90 & 110 & 40 & 50 & $<30$ & 40 & 40 & 50 & 40 \\
\hline $\mathrm{Ga}$ & ppm & 1 & 22 & 19 & 21 & 20 & 19 & 18 & 18 & 19 & 13 & 18 & 18 & 18 & 19 \\
\hline $\mathrm{Ge}$ & ppm & 0.5 & 1.6 & 1.7 & 2.4 & 2.3 & 1.2 & 2 & 1.8 & 1.9 & 2 & 1.1 & 1.1 & 1.3 & 1.2 \\
\hline As & ppm & 5 & $<5$ & $<5$ & $<5$ & $<5$ & $<5$ & $<5$ & $<5$ & $<5$ & $<5$ & $<5$ & $<5$ & $<5$ & $<5$ \\
\hline $\mathrm{Rb}$ & ppm & 1 & 68 & 51 & 29 & 9 & 47 & 46 & 74 & 58 & 95 & 73 & 74 & 69 & 71 \\
\hline $\mathrm{Sr}$ & ppm & 2 & 391 & 295 & 360 & 296 & 349 & 310 & 309 & 371 & 135 & 243 & 199 & 204 & 230 \\
\hline$Y$ & ppm & 0.5 & 34.1 & 32.7 & 36.6 & 35.6 & 32.7 & 32.1 & 23.7 & 20.1 & 10 & 17.9 & 17.6 & 18.6 & 16.2 \\
\hline $\mathrm{Zr}$ & ppm & 1 & 255 & 245 & 260 & 255 & 231 & 219 & 124 & 145 & 13 & 159 & 152 & 168 & 178 \\
\hline $\mathrm{Nb}$ & ppm & 0.2 & 14.3 & 15.2 & 14.9 & 15 & 13.4 & 14.8 & 8 & 7.9 & 5.6 & 6.3 & 6.4 & 7.1 & 7.6 \\
\hline
\end{tabular}


TABLE 1. Continued

\begin{tabular}{|c|c|c|c|c|c|c|c|c|c|c|c|c|c|c|c|}
\hline & Unit & $\mathrm{DL}$ & $\begin{array}{l}\text { Dyke } \\
1\end{array}$ & $\begin{array}{l}\text { Dyke } \\
2\end{array}$ & $\begin{array}{l}\text { Dyke } \\
3\end{array}$ & $\begin{array}{l}\text { Dyke } \\
4\end{array}$ & $\begin{array}{l}\text { Dyke } \\
5\end{array}$ & $\begin{array}{l}\text { Dyke } \\
6\end{array}$ & QMonz & Grd & GrPeg & LeuGr & LeuGr & LeuGr & LeuGr \\
\hline Mo & ppm & 2 & $<2$ & $<2$ & $<2$ & $<2$ & $<2$ & $<2$ & $<2$ & $<2$ & $<2$ & $<2$ & $<2$ & $<2$ & $<2$ \\
\hline $\mathrm{Ag}$ & ppm & 0.5 & 0.8 & 0.7 & 0.7 & 0.7 & 0.7 & 0.6 & $<0.5$ & 0.5 & $<0.5$ & 0.5 & $<0.5$ & 0.6 & 0.5 \\
\hline $\ln$ & ppm & 0.1 & 0.1 & $<0.1$ & $<0.1$ & $<0.1$ & $<0.1$ & 0.1 & $<0.1$ & $<0.1$ & $<0.1$ & $<0.1$ & $<0.1$ & $<0.1$ & $<0.1$ \\
\hline Sn & ppm & 1 & 2 & 1 & 1 & 1 & $<1$ & 1 & 1 & 1 & 4 & $<1$ & $<1$ & $<1$ & 1 \\
\hline $\mathrm{Sb}$ & ppm & 0.2 & $<0.2$ & $<0.2$ & $<0.2$ & $<0.2$ & $<0.2$ & $<0.2$ & $<0.2$ & $<0.2$ & $<0.2$ & $<0.2$ & $<0.2$ & $<0.2$ & $<0.2$ \\
\hline Cs & ppm & 0.1 & 2.2 & 1.4 & 1.3 & 0.6 & 1.7 & 2.6 & 2.2 & 1.4 & 2.5 & 1.9 & 2.1 & 3 & 1.9 \\
\hline $\mathrm{Ba}$ & ppm & 2 & 776 & 483 & 348 & 61 & 412 & 619 & 783 & 624 & 452 & 772 & 644 & 619 & 627 \\
\hline La & ppm & 0.05 & 40.2 & 43.2 & 42 & 38.3 & 37.5 & 39.1 & 34.3 & 31.8 & 4.69 & 27.8 & 27.1 & 30 & 30.5 \\
\hline $\mathrm{Ce}$ & ppm & 0.05 & 86.2 & 89.3 & 90.2 & 82.4 & 80.5 & 83.8 & 69.7 & 64.5 & 9.98 & 56.3 & 56.1 & 60.6 & 60.7 \\
\hline $\mathrm{Pr}$ & ppm & 0.01 & 10.5 & 10.9 & 11.1 & 10.1 & 9.79 & 10.3 & 7.9 & 7.39 & 1.18 & 6.41 & 6.37 & 7.04 & 6.95 \\
\hline $\mathrm{Nd}$ & ppm & 0.05 & 41.7 & 43.7 & 43.4 & 40.7 & 39.3 & 42 & 30.4 & 28.1 & 4.38 & 24.3 & 24.3 & 26 & 26 \\
\hline $\mathrm{Sm}$ & ppm & 0.01 & 8.58 & 8.32 & 8.9 & 8.22 & 8.09 & 8.5 & 6.1 & 5.41 & 1.62 & 4.76 & 4.59 & 5.26 & 4.98 \\
\hline $\mathrm{Eu}$ & ppm & 0.005 & 1.91 & 1.87 & 2 & 1.72 & 1.83 & 1.91 & 1.04 & 1.11 & 0.413 & 0.999 & 0.964 & 1.01 & 1.11 \\
\hline $\mathrm{Gd}$ & ppm & 0.01 & 6.82 & 6.87 & 7.46 & 7.03 & 6.58 & 6.92 & 4.84 & 4.57 & 1.64 & 3.72 & 3.82 & 3.91 & 3.7 \\
\hline $\mathrm{Tb}$ & ppm & 0.01 & 1.04 & 1.07 & 1.13 & 1.1 & 1.04 & 1.08 & 0.74 & 0.65 & 0.33 & 0.56 & 0.57 & 0.6 & 0.56 \\
\hline Dy & ppm & 0.01 & 6.39 & 6.07 & 6.84 & 6.46 & 6.12 & 6.09 & 4.16 & 3.64 & 2.03 & 3.24 & 3.18 & 3.5 & 3.21 \\
\hline $\mathrm{Ho}$ & ppm & 0.01 & 1.2 & 1.12 & 1.3 & 1.21 & 1.18 & 1.18 & 0.8 & 0.72 & 0.37 & 0.61 & 0.61 & 0.65 & 0.58 \\
\hline $\mathrm{Er}$ & ppm & 0.01 & 3.5 & 3.24 & 3.59 & 3.41 & 3.34 & 3.25 & 2.2 & 1.97 & 0.86 & 1.72 & 1.7 & 1.74 & 1.57 \\
\hline $\mathrm{Tm}$ & ppm & 0.005 & 0.489 & 0.46 & 0.493 & 0.49 & 0.467 & 0.466 & 0.328 & 0.278 & 0.123 & 0.245 & 0.233 & 0.24 & 0.21 \\
\hline$Y b$ & ppm & 0.01 & 3.11 & 2.82 & 3.22 & 3.14 & 3.04 & 2.98 & 2.16 & 1.71 & 0.84 & 1.51 & 1.5 & 1.5 & 1.33 \\
\hline Lu & ppm & 0.002 & 0.484 & 0.425 & 0.501 & 0.454 & 0.462 & 0.472 & 0.327 & 0.254 & 0.128 & 0.21 & 0.23 & 0.22 & 0.213 \\
\hline $\mathrm{Hf}$ & ppm & 0.1 & 6 & 5.7 & 6.2 & 5.9 & 5.2 & 5.4 & 3.9 & 4.1 & 0.6 & 4 & 3.9 & 4.3 & 4.3 \\
\hline $\mathrm{Ta}$ & ppm & 0.01 & 0.87 & 0.9 & 0.92 & 0.86 & 0.97 & 0.81 & 1.39 & 0.87 & 1.8 & 1.11 & 1.28 & 1.14 & 0.99 \\
\hline W & ppm & 0.5 & 54.4 & 55.1 & 79.6 & $\begin{array}{r}52.9 \\
<\end{array}$ & 102 & 30.9 & 347 & 195 & 429 & 303 & 407 & 364 & 233 \\
\hline TI & ppm & 0.05 & 0.35 & 0.27 & 0.16 & 0.05 & 0.22 & 0.26 & 0.45 & 0.35 & 0.45 & 0.37 & 0.4 & 0.36 & 0.36 \\
\hline $\mathrm{Pb}$ & ppm & 5 & 23 & 15 & 8 & 6 & 6 & $<5$ & 14 & 11 & 21 & 8 & 9 & 6 & $<5$ \\
\hline $\mathrm{Bi}$ & ppm & 0.1 & 0.8 & 0.2 & 0.3 & 0.8 & $<0.1$ & $<0.1$ & $<0.1$ & $<0.1$ & $<0.1$ & $<0.1$ & $<0.1$ & $<0.1$ & $<0.1$ \\
\hline Th & ppm & 0.05 & 5.53 & 6.13 & 5.72 & 5.5 & 5.29 & 5.8 & 9.89 & 7.69 & 1.41 & 7.23 & 7.22 & 7.33 & 7.96 \\
\hline U & ppm & 0.01 & 1.15 & 1.06 & 8.31 & 2.04 & 0.91 & 0.99 & 1.36 & 1.12 & 2.26 & 1.62 & 1.99 & 1.62 & 1.73 \\
\hline Mg\# & & & 60.1 & 59.7 & 54 & 59.1 & 59.9 & 59 & 31.49 & 43.99 & 44.20 & 49.09 & 45.85 & 51.60 & 51.16 \\
\hline
\end{tabular}


were sent to University of California (UC) Santa Barbara (United States of America) for in situ U-Pb dating via Laser Ablation Inductively Coupled Plasma Mass Spectrometry (LA-MC-ICPMS) following the procedures outlined in Spencer et al. (2013), Kylander-Clark et al. (2013) and Kylander-Clark (2020). Samples were ablated with a Photon Machines Excite 193 nm laser ablation system equipped with a HelEx cell, using a spot size of $25 \mu \mathrm{m}$ and a repetition rate of $5 \mathrm{~Hz}$. Aerosol from the laser was carried in a mixture of $\mathrm{He}$ and $\mathrm{Ar}$ and analyzed by a Nu Instruments Plasma High Resolution Multi Collector Inductively Coupled Plasma Mass Spectrometry (HR MC-ICPMS) for U-Pb analysis and by an Agilent 7700X for trace-element analysis. For titanite, Reference Material (RM) MKED (Spandler et al., 2016) was used to correct for instrumental offset of isotopic ratios, and BLR (Aleinikoff et al., 2007) and Y1710C5 (Kylander-Clark et al., 2008) were used to ensure accuracy; secondary RMs yielded ages within $2 \%$ of accepted values. Allanite analysis and data reduction required a two-step approach, first using NIST612 glass to correct for instrument drift and bias in ${ }^{207} \mathrm{~Pb} /{ }^{206} \mathrm{~Pb}$ and ${ }^{206} \mathrm{~Pb} /{ }^{238} \mathrm{U}$ ratios, followed by a correction of the ${ }^{206} \mathrm{~Pb} /{ }^{238} \mathrm{U}$ ratio such that RMs SISS, BONA, and TARA yielded ages within $2 \%$ of accepted values (von Blanckenburg et al., 1992; Smye et al., 2014). Trace-elements were determined using NIST612 as the primary RM and ${ }^{28} \mathrm{Si}$ as the internal standard, assuming $19.2 \mathrm{wt} \%$ in titanite and $14 \mathrm{wt} \%$ in allanite.

In order to recognize possible genetic relationships between the LGL dykes, their host rocks and other Variscan magmatic occurrences, their chemical composition has been compared with those of several rocks that represent some of the compositional end members of Variscan magmatism of Western Europe. These are calc-alkaline lamprophyres and lamproites to represent different extents of SCLM enrichment, Permian calc-alkaline volcanic andesites and alkaline basalts from eastern Pyrenees and the Iberian Ranges, Permian alkaline lamprophyres from the Iberian Central System (ICS) to represent asthenospheric influences, and ultramafic (appinites) to felsic intrusives of the Catalan Coastal Batholith and appinites from NW Iberia to represent main Variscan mantle-crust magmatism (compiled data in Appendix I).

\section{FIELD OBSERVATIONS AND PETROGRAPHY}

Les Guilleries lamprophyres crop out in a narrow zone $\left(<2 \mathrm{~km}^{2}\right)$ on the walls of a unique meander of the Ter River, which formed by Alpine rejuvenation of the terrane. The meander probably reflects the strength to weathering of the Variscan granitoids that host the lamprophyres. This zone is highly fractured and highly altered in some places, reflecting multiple superimposed processes heterogeneously affecting the rocks at the meter scale.
Les Guilleries lamprophyres appear as a vertical to sub-vertical dyke swarm with branching dykes of some centimeters to meters in width and tens of meters in length, emplaced in the intersection of two perpendicular fault systems oriented NE-SW and NW-SE (Fig. 1A-B). They are dark colored that contrasts with the white to red granitoid hosts (quartz-monzonites, granodiorites, leucogranites and granitic pegmatites) and the grayish lower Paleozoic schists and marbles (Fig. 1C-E). The dykes are approximately E-W oriented although segmentation of the dykes in other directions is noticeable at decimeter- to centimeter-scale, along fractures and joints. The dykes have sharp contacts with their host rocks, with no evident fracturing at the tips of single veins (Fig. 1C). In hand specimens, all lamprophyres present a fine porphyritic texture with millimetric green phenocrysts and some sulfides in a micrometric groundmass, with variable spatial distribution of the phenocrysts at a centimetric scale.

The phenocrysts consist of mostly light green chlorite as seen in thin section, possibly altering pyroxene, amphibole and/ or phlogopite crystals, with variable amounts of secondary epidote, albite and calcite, with some pyrite and chalcopyrite inclusions (Fig. 2A-C). These altered phenocrysts varied in shape and size $(0.5-1.5 \mathrm{~mm})$. Millimeter size subhedral anortithe-albite phenocrysts are also present in all samples with varying proportions, commonly showing sericite and hematite inclusions (Fig. 2C). Millimetric dark brown amphibole phenocrysts up to $1.5 \mathrm{~mm}$, strongly replaced by chlorite and albite, are only present in some dykes, which appear to be the less altered (Fig. 2D). Some dykes contain millimetric xenocrysts of rimmed alkali feldspar whereas quartz occurs sporadically in others (Fig. 2E). Veins of epidote, calcite or both, of micrometric to millimetric width, are present in all dykes but are more common in the most altered ones (Fig. 2F).

The groundmass of the less altered dykes is composed of primary amphibole (actinolite to hornblende with cores slightly enriched in titanium and alkalis), anortithe, albite, K-feldspar and minor titanite, epidote, calcite, ilmenite, allanite, fluoroapatite, spinel, zircon, and pyrite together with secondary calcite, epidote, chlorite, albite, titanite and quartz (Fig. 2G-H). A diminishing content of amphibole, anorthite and K-feldespar along with an increasing content of albite, chlorite, epidote, titanite and quartz are observed with increasing alteration. Thus, the most altered dykes are dominated by secondary chlorite and albite phenocrysts, with a groundmass dominated by albite and chlorite (Fig. 2I) and minor epidote, titanite, ilmenite, quartz and rutile.

\section{WHOLE-ROCK MAJOR AND TRACE ELEMENT CHEMISTRY}

Major- and trace-element concentration of the LGL dykes are presented in Table 1. Even though some dykes appear 


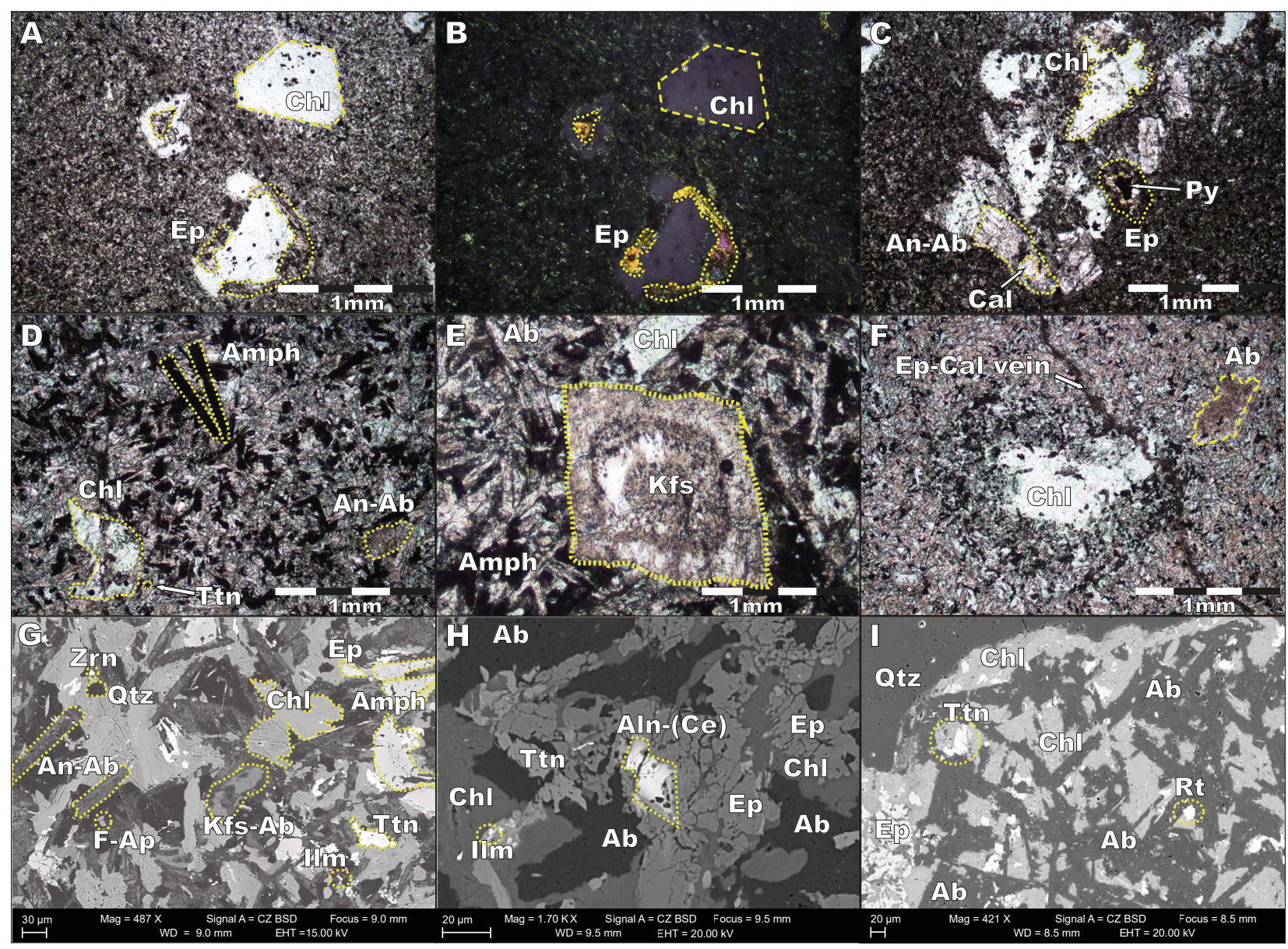

FIGURE 2. Photographs (A-F) and Back-Scattered Electron (BSE) images (G-I). A) Chloritized phenocrysts with inclusions and rims of epidote, in a fine grained matrix of mainly chloritized domains (green) and feldespatic domains (white), with opaque minerals mainly altered amphibole and titanite (black). B) Figure 2A in cross-polarised light. C) Glomeroporphyritic texture of chloritized mafic phenocrysts and albitized anorthite phenocrysts, with minor epidote and calcite, and pyrite inclusions. D) Elongated dark brown amphibole phenocrysts in a less altered sample. E) Sporadic rimmed alkali feldspar xenocryst. F) Chloritized phenocryst surrounded by tiny crystals of amphibole, chlorite and anorthite-albite (commonly known as "ocelli") reflecting disequilibrium conditions. Reddish hematitized albite phenocryst and epidote-calcite veins are also shown. G) Representative sample of the less altered dykes. It shows primary amphibole (mainly actinolite and hornblende), anorthite, K-feldspar, titanite, ilmenite, F-apatite, zircon and secondary chlorite, epidote, albite and quartz. H) Magmatic allanite-(Ce) affected by epidotization, chloritization and albitization (in that order). Some allanite crystals are surrounded by epidote coronas (not shown). I) Representative sample of the most altered dykes, showing predominance of secondary albite in the lamprophyre matrix, followed by chlorite and minor epidote, titanite and rutile. In the top left, part of a quartz xenocryst shows slightly reabsorbed boundaries. Ab: albite. Aln-(Ce): allanite-(Ce). Amph: amphibole. An: anorthite. Cal: calcite. Chl: chlorite. Ep: epidote. F-Ap: fluoroapatite. IIm: ilmenite. Kfs: k-feldespar. Py: pyrite. Qtz: quartz. Rt: rutile. Ttn: titanite. Zrn: zircon.

more altered than others, they all present similar values of $\mathrm{MgO}$ (5.3-6.8\%; Mg\# 54-60), $\mathrm{Al}_{2} \mathrm{O}_{3}(15.2-16.5 \%), \mathrm{Fe}_{2} \mathrm{O}_{3} \mathrm{~T}$ (8.0-9.2\%), $\mathrm{TiO}_{2}$ (1.3-1.5\%), $\mathrm{P}_{2} \mathrm{O}_{5}(0.37-0.42 \%), \mathrm{MnO}(0.13-$ $0.20 \%$ ) and Loss On Ignition (LOI, 4.08-5.29\%). However, the concentration is more variable in $\mathrm{SiO}_{2}(49.8-53.6 \%), \mathrm{CaO}$ (3.6-6.6\%), $\mathrm{Na}_{2} \mathrm{O}(2.4-4.4 \%)$ and $\mathrm{K}_{2} \mathrm{O}(0.2-2.1 \%)$. These compositions plot in the calc-alkaline field (Fig. 3A) in the $\mathrm{Na}_{2} \mathrm{O}+\mathrm{K}_{2} \mathrm{O}$ vs $\mathrm{SiO}_{2}$ diagram of Rock (1991); ranging from the limit of the shoshonite to low-K calc-alkaline suites (Fig. $3 \mathrm{~B}$ ) in a $\mathrm{K}_{2} \mathrm{O}$ vs $\mathrm{SiO}_{2}$ diagram (Peccerillo and Taylor, 1976). These lamprophyres contain more iron than magnesium $\left(\mathrm{Fe}_{2} \mathrm{O}_{3} \mathrm{~T}>\mathrm{MgO}\right)$, more sodium than potassium $\left(\mathrm{K}_{2} \mathrm{O} / \mathrm{Na}_{2} \mathrm{O}<1\right)$, and the $\mathrm{K}_{2} \mathrm{O}$ content is generally inversely correlated with that of $\mathrm{Na}_{2} \mathrm{O}$ (Fig. 3C). Silica concentration is directly proportional to $\mathrm{Na}_{2} \mathrm{O}$ concentration and inversely related to $\mathrm{CaO}$ and $\mathrm{K}_{2} \mathrm{O}$ contents; these compositional variations are in agreement with the abundance of albite, anorthite and K-feldspar described in the Petrography section. All dykes show similar immobile $\mathrm{Zr}$ / $\mathrm{Ti}$ and $\mathrm{Nb} / \mathrm{Y}$ ratios, corresponding to andesite to sub-alkaline basalt affinities (Fig. 3D).

Enrichments in LILE (K, Ba, Cs, Rb, Th) and HFSE (Zr, $\mathrm{Hf}$ ), positive $\mathrm{Pb}$ and negative $\mathrm{Nb}, \mathrm{Ta}, \mathrm{Sr}$ and $\mathrm{Ti}$ anomalies can be observed for most dykes in a trace-element pattern normalized to primitive mantle values diagram (Fig. 4A). These are common features for calc-alkaline lamprophyres (Rock, 1991) and are also observed in Aiguablava dykes (Ubide et al., 2010). 

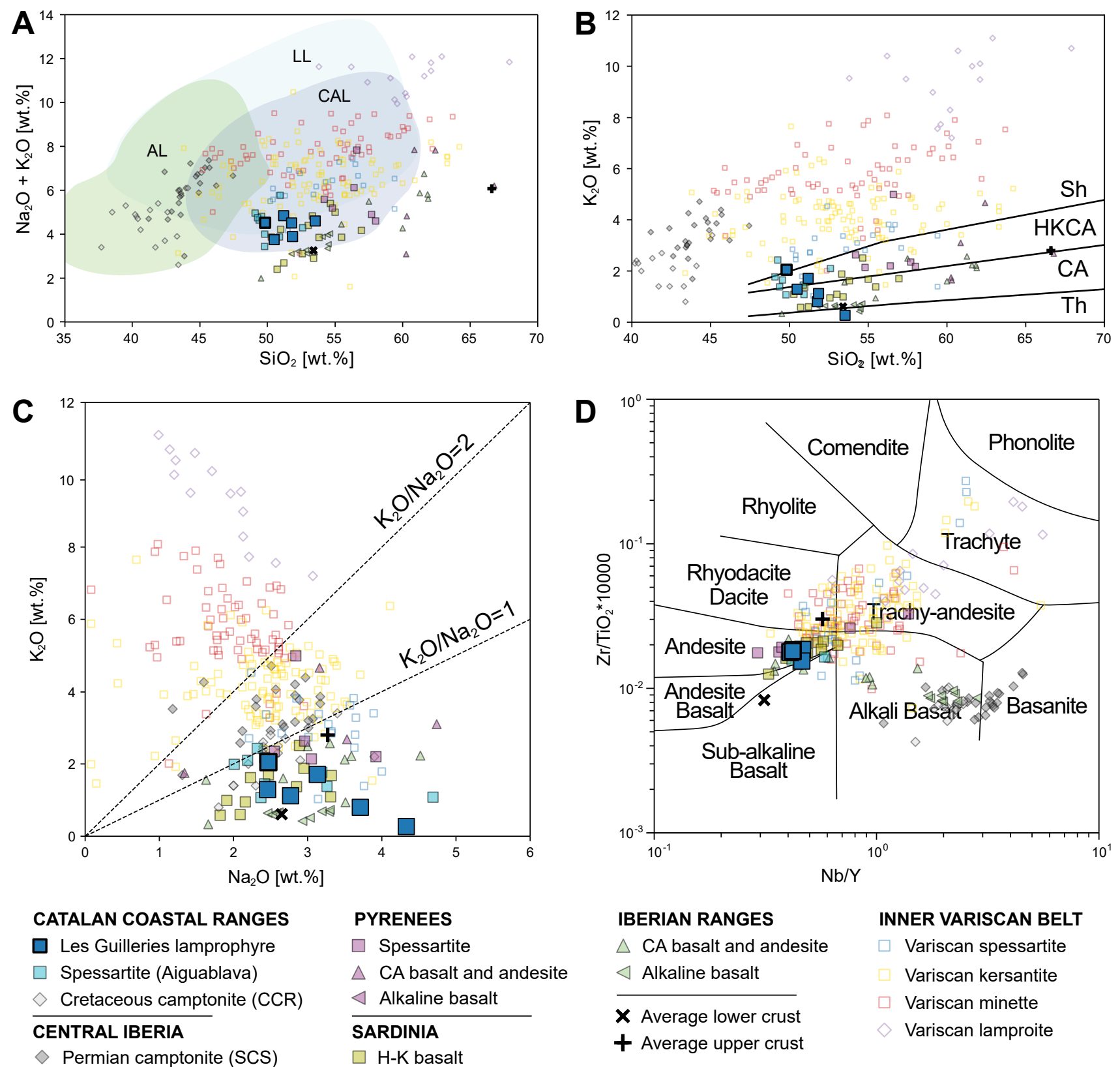

\begin{tabular}{l} 
PYRENEES \\
$\square$ Spessartite \\
$\triangle$ CA basalt and andesite \\
$\triangleleft$ Alkaline basalt \\
\hline SARDINIA \\
$\square$ H-K basalt
\end{tabular}

\section{IBERIAN RANGES}

$\triangle$ CA basalt and andesite

$\triangleleft$ Alkaline basalt

X Average lower crust

+ Average upper crust
INNER VARISCAN BELT

Variscan spessartite

Variscan kersantite

Variscan minette

Variscan lamproite

FIGURE 3. A) $\mathrm{Na}_{2} \mathrm{O}+\mathrm{K}_{2} \mathrm{O}+$ vs. $\mathrm{SiO}_{2}$ diagram of lamprophyre classification (fields after Rock,1991). AL: alkaline lamprophyre. CAL: calc-alkaline lamprophyre. LL: lamproite. B) $\mathrm{K}_{2} \mathrm{O}$ vs. $\mathrm{SiO}_{2}$ classification diagram for orogenic magmatic rocks (Peccerillo and Taylor, 1976). Sh: shoshonite. HKCA: high-K calc-alkaline. CA: calc-alkaline. Th: tholeitic. C) $\mathrm{K}_{2} \mathrm{O}$ vs. $\mathrm{Na}_{2} \mathrm{O}$ showing that all $\mathrm{LGL}$ dykes have $\mathrm{K}_{2} \mathrm{O} / \mathrm{Na}_{2} \mathrm{O}<1$. D) $\mathrm{Zr} / \mathrm{TiO} 2$ vs. $\mathrm{Nb} / \mathrm{Y}$ diagram (after Winchester and Floyd (1977)) in which LGL dykes plot in the fields of andesite to sub-alkaline basalt. Data sources: Aiguablava spessartites, Enrique (2009) and Ubide et al. (2010); Cretaceous camptonites from the Catalan Coastal Ranges (CCR), Ubide (2013); camptonites from the Spanish Central System, Orejana et al. (2008); spessartites from Maladeta (Pyrenees), Perini et al. (2004); high-K basaltic andesite dykes from Sarrabus (Sardinia), Ronca et al. (1999); Permian volcanic calc-alkaline andesites and alkaline basalts from eastern Pyrenees (Serra del Cadí, Innocent et al., 1994) and the south-eastern Iberian Ranges (Lago et al., 2004; Lago et al., 2012). Variscan spessartites, kersantites and minettes from the inner parts of the Variscan Belt are from: minettes, kersantites and spessartites from Vosges, Schwarzwald and Black Forest, Soder (2017); kersantites and spessartites from Erzgebirge in Bohemian massif, Seifert (2008); lamproites from Bohemian massif, Krmíček et al. (2015). Average lower and upper crust from Rudnick and Gao (2003).

Chondrite-normalized REE patterns also show similar fractionation for all dykes, independent of their alteration degree, with enrichments up to two orders of magnitude with respect to chondrite, enrichments in LREE with respect to Middle Rare Earth Elements (MREE) and HREE, and negative Eu anomaly (Fig. 4B). In spite of the similarities, significant variations among LGL dykes show up for mobile elements and the highest differences occur for $\mathrm{F}, \mathrm{Ba}, \mathrm{Sr}, \mathrm{Cr}, \mathrm{Zn}, \mathrm{Ni}, \mathrm{Rb}, \mathrm{Pb}$ and $\mathrm{Cs}$ concentrations. Figure 5 shows that $\mathrm{Ba}, \mathrm{Rb}$ and $\mathrm{Cs}$ concentrations decrease with increasing $\mathrm{Na}_{2} \mathrm{O}$ content. A similar trend is observed for $\mathrm{Pb}, \mathrm{Sr}, \mathrm{Cr}$ and $\mathrm{Ni}$ concentrations, although it is less 
evident. On the other hand, $\mathrm{Zn}$ concentration increases with $\mathrm{Na}_{2} \mathrm{O}$ (Fig. 5).

LGL dykes have major- and trace-element concentrations similar to the Aiguablava spessartites, but slightly more enriched in most HFSE and REE (Fig. 4A). With respect to other Variscan K-rich mafic dykes, the LGL dykes present lower enrichments in LILE, HFSE and REE in general, but within the ranges of variation of Variscan spessartites (Fig. 4A). LGL dykes also show major- and trace-element concentrations similar to high-K basaltic andesite dykes from Sardinia (Fig. 4A).

The plots of Figure 6 show that Variscan enriched mafic dykes show a wide variation in the concentration of several elements at similar $\mathrm{MgO}$ content, with clear differences between calc-alkaline (orogenic) and alkaline (anorogenic) lamprophyres, as the later show higher $\mathrm{TiO}_{2}$ and $\mathrm{Fe}_{2} \mathrm{O}_{3}$ content. LGL dykes cluster together with Aiguablava spessartites and high-K basaltic andesite dykes from Sardinia, showing characteristic high values of $\mathrm{Al}_{2} \mathrm{O}_{3}, \mathrm{Fe}_{2} \mathrm{O}_{3}$ and low values of $\mathrm{K}_{2} \mathrm{O}$ and total REE, which are closer to average lower crustal values than spessartites, kersantites, minnetes and lamproites located in more internal positions within the Variscan belt (closer to the Rheic suture, here referred for simplicity as "Inner Variscan Belt"). LGL dykes also show $\mathrm{Al}_{2} \mathrm{O}_{3}, \mathrm{CaO}, \mathrm{Fe}_{2} \mathrm{O}_{3}, \mathrm{~K}_{2} \mathrm{O}$ and LOI similar to some calc-alkaline basalts and andesites from Permian basins in the Eastern Pyrenees and Iberian Ranges, but with generally higher $\mathrm{TiO}_{2}, \mathrm{P}_{2} \mathrm{O}_{5}$ and REE contents.

With respect to Variscan intrusives of the Catalan Coastal Batholith, LGL dykes have higher concentrations in $\mathrm{K}_{2} \mathrm{O}$, $\mathrm{TiO}_{2}, \mathrm{P}_{2} \mathrm{O}_{5}$ and $\mathrm{LOI}$ at the same silica content, whereas in the rest of major-element concentrations, LGL dykes are similar
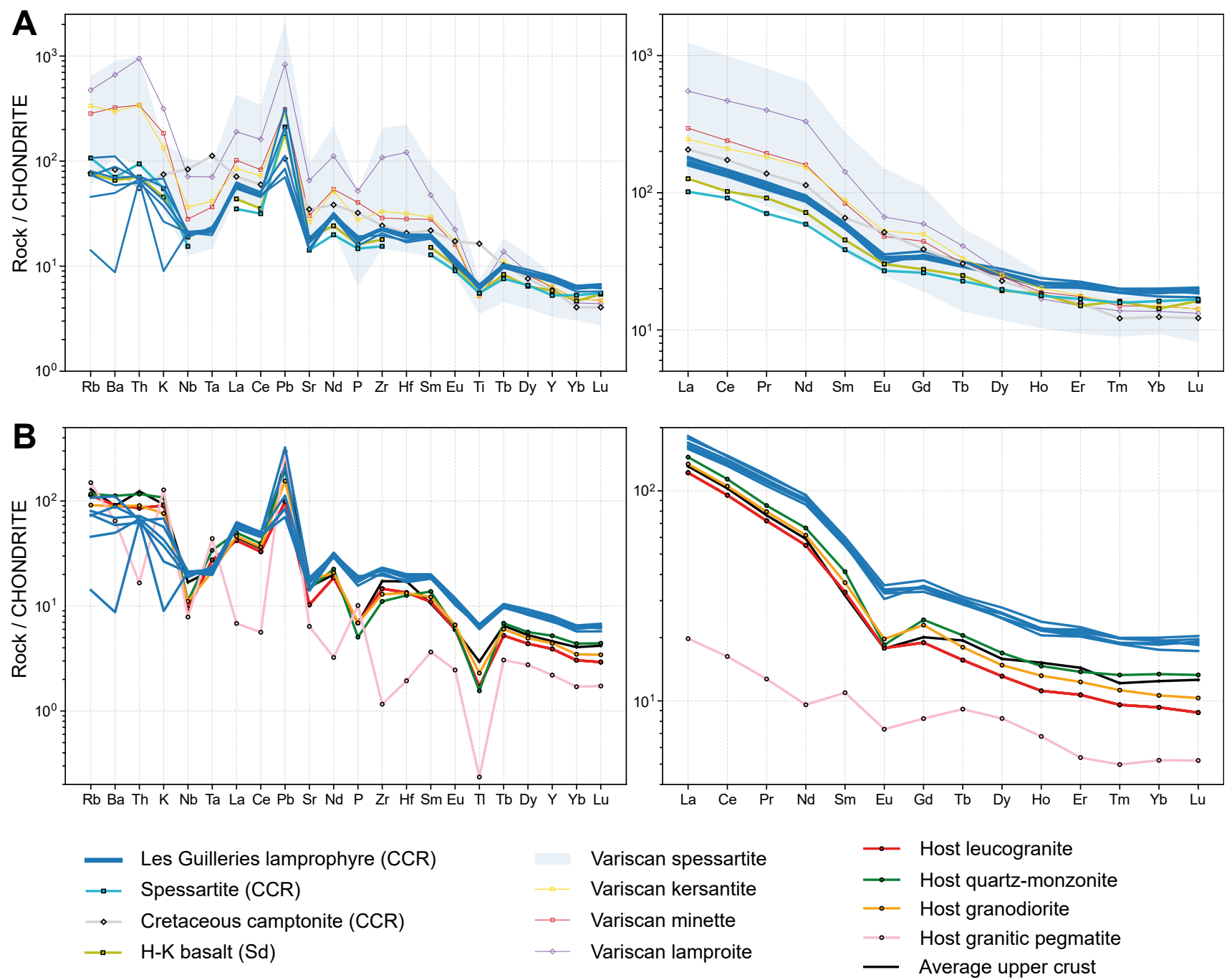

FIGURE 4. Primitive mantle-normalized trace element patterns (left) and chondrite-normalized REE patterns (right) of LGL dykes with respect to A) Variscan calc-alkaline lamprophyres and lamproites and host, B) Variscan granitoids. Median values are shown except for LGL dykes and the dark area represent the wide compositional variation of Variscan spessartites. Normalizing values of primitive mantle and chondrite from Sun and McDonough (1989) and McDonough and Sun (1995), respectively. Data sources as in Figure 3. 
to those of gabbros from the appinite suits of Susqueda and Montnegre and fall within the known calc-alkaline trend of post-collisional Variscan magmatism in the CCR (Fig. 7).

\section{Sr-Nd isotopes}

Whole-rock Sr-Nd isotopic compositions of LGL dykes are presented in Table $2 .{ }^{87} \mathrm{Sr} /{ }^{86} \mathrm{Sr}_{\mathrm{i}}$ values range from
0.708510 to $0.711272 \pm 0.000005$, where the highest values are found in the most altered samples. ${ }^{143} \mathrm{Nd} /{ }^{144} \mathrm{Nd}$ ratios show a narrower range, between 0.512231 and 0.512246 \pm 0.000002 , with calculated $\varepsilon \mathrm{Nd}_{\mathrm{i}}$ from -5.23 to -4.63 (Fig. 8). Initial Sr-Nd isotopic compositions of LGL dykes plot within the ranges of variation of Variscan minnetes, kersantites and spessartites from Erzgebirge, Schwarzwald, Vosges and Pyrenees, with high ${ }^{87} \mathrm{Sr}^{86} \mathrm{Sr}_{\mathrm{i}}$ and low $\varepsilon \mathrm{Nd}_{\mathrm{i}}$
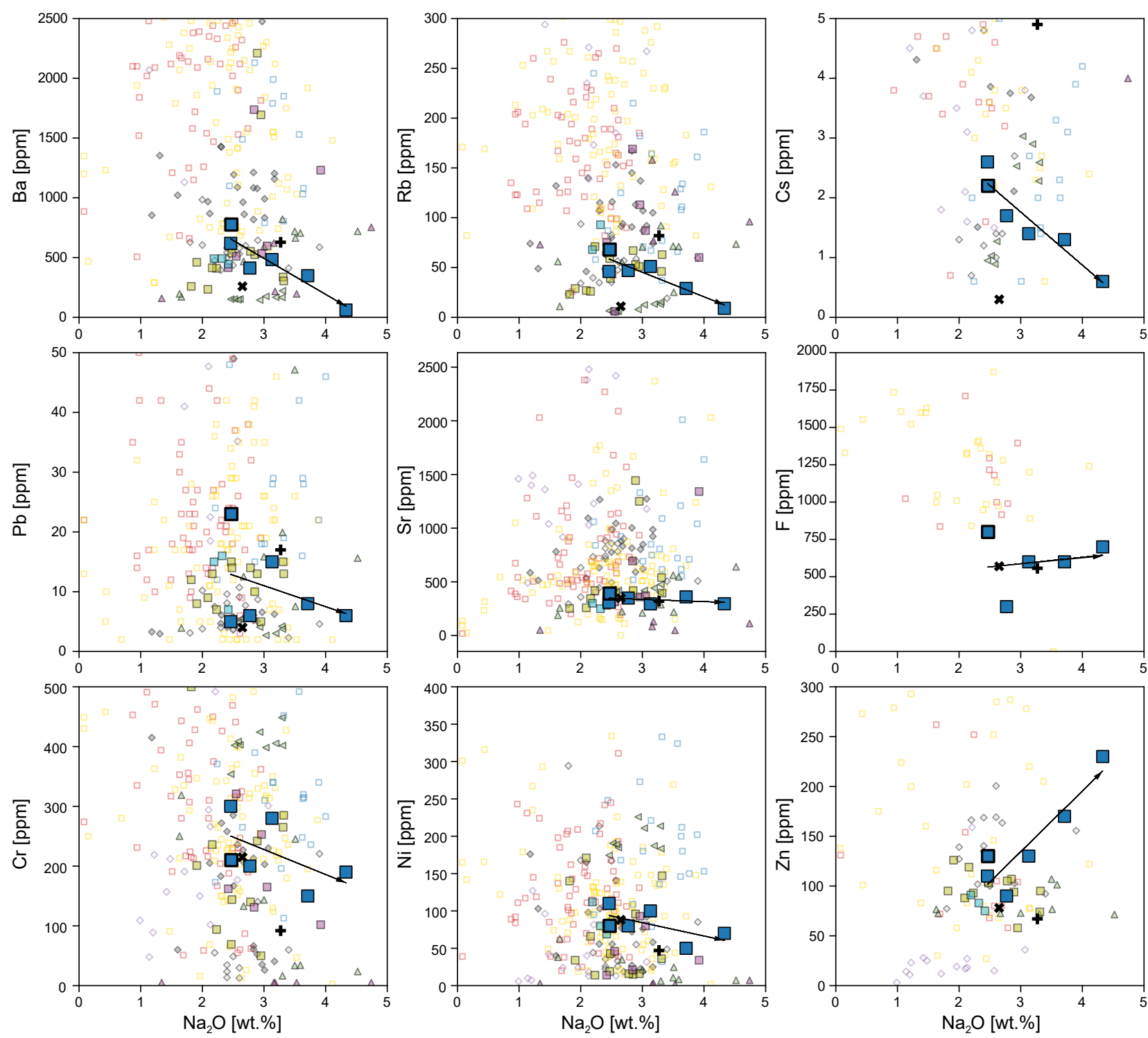

\section{CATALAN COASTAL RANGES}

$\square$ Les Guilleries lamprophyre

$\square$ Spessartite (Aiguablava)

$\diamond$ Cretaceous camptonite (CCR)

\section{CENTRAL IBERIA}

$\diamond$ Permian camptonite (SCS)

\section{PYRENEES}

$\square$ Spessartite

$\triangle$ CA basalt and andesite

$\triangleleft$ Alkaline basalt

SARDINIA

$\square \mathrm{H}-\mathrm{K}$ basalt
IBERIAN RANGES

$\triangle$ CA basalt and andesite

$\triangleleft$ Alkaline basalt

$\mathbf{X}$ Average lower crust

+ Average upper crust
INNER VARISCAN BELT

$\square$ Variscan spessartite

Variscan kersantite

$\square$ Variscan minette

$\checkmark$ Variscan lamproite

FIGURE 5. Trace element concentrations vs. $\mathrm{Na}_{2} \mathrm{O}$ of $\mathrm{LGL}$ dykes showing the most mobile elements during alteration. Arrows point towards increasing albitization. Data sources as in Figure 3. 
typical of variably enriched lithospheric mantle sources (Fig. 8A). In the ICS the isotopic composition of pyroxenitic and hornblenditic xenoliths overlap with the lamprophyre compositional fields, implying that the mantle beneath the ICS has a "two-pole composition": one pole is a depleted isotopic component with high $\varepsilon \mathrm{Nd}_{\mathrm{i}}$ (3.5 to 7.1) and low ${ }^{87} \mathrm{Sr}^{\circ}{ }^{6} \mathrm{Sr}_{\mathrm{i}}(0.7029$ to 0.7044$)$; the second pole is an enriched lithospheric mantle with low $\varepsilon \mathrm{Nd}_{\mathrm{i}}$ values (0.9 to 1.5$)$ and relatively high ${ }^{87} \mathrm{Sr} /{ }^{86} \mathrm{Sr}_{\mathrm{i}}(0.7043$ to 0.7051$)$ (Orejana et al., 2006). LGL dykes show even higher ${ }^{87} \mathrm{Sr} /{ }^{86} \mathrm{Sr}_{\mathrm{i}}$ (up to 0.7112 ) and lower $\varepsilon \mathrm{Nd}_{\mathrm{i}}(-5.23$ to -4.63$)$, clustering together with high-K basalts from Sardinia, and Permian calc-alkaline volcanics from the Iberian Ranges and Eastern Pyrenees (Fig. 8A).
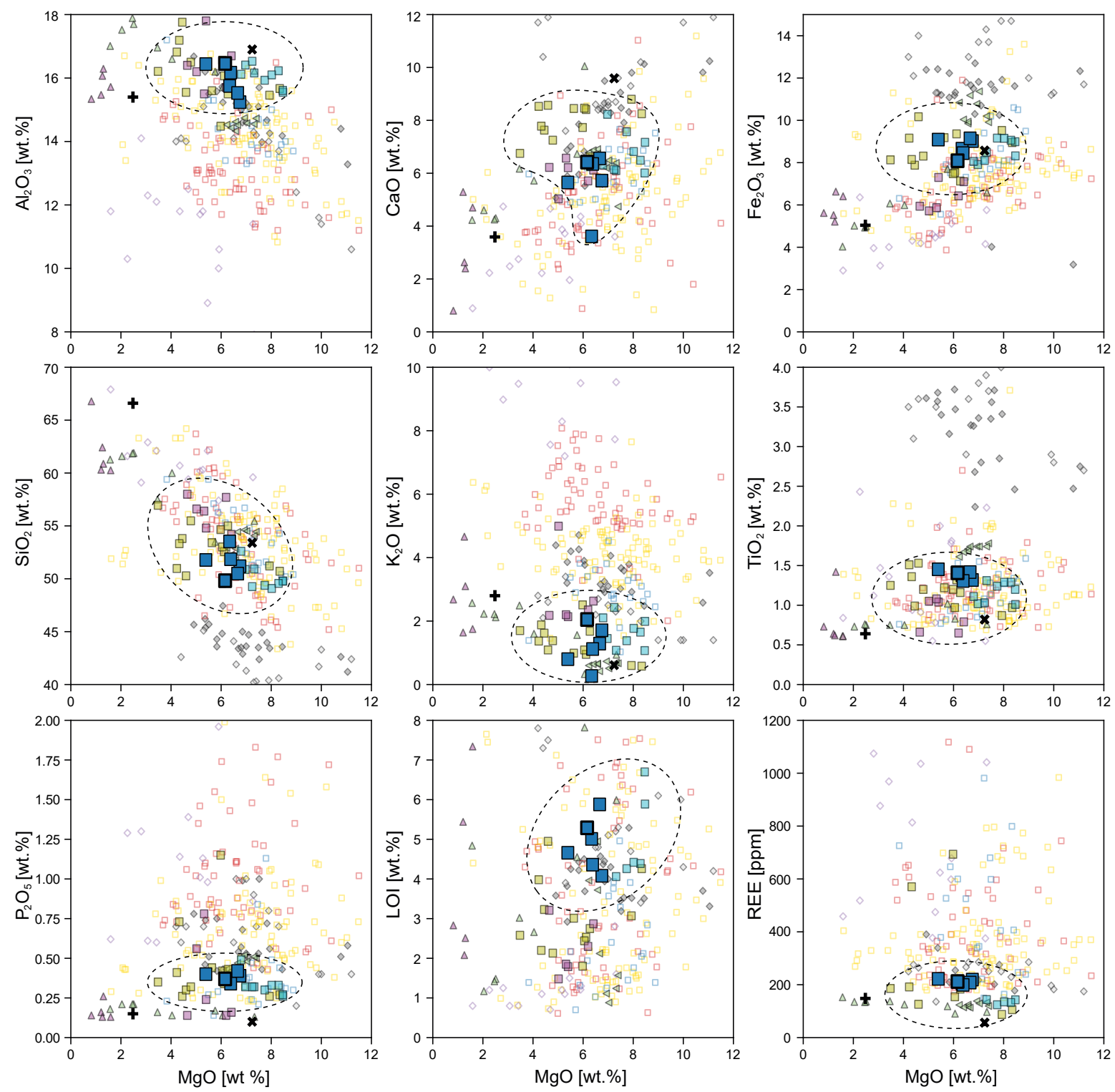

\section{CATALAN COASTAL RANGES}

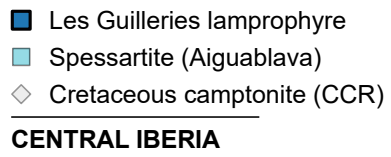

CENTRAL IBERIA

$\diamond$ Permian camptonite (SCS)

\section{PYRENEES}

$\square$ Spessartite

$\triangle$ CA basalt and andesite

$\triangleleft$ Alkaline basalt

SARDINIA

$\square$ H-K basalt

\section{IBERIAN RANGES}

$\triangle$ CA basalt and andesite

$\triangleleft$ Alkaline basalt

X Average lower crust

+ Average upper crust
INNER VARISCAN BELT

$\square$ Variscan spessartite

Variscan kersantite

$\square$ Variscan minette

> Variscan lamproite

FIGURE 6. Major element constituents vs. MgO and total REE content of LGL dykes with respect to other Variscan lamprophyres and lamproites. The composition of LGL dykes is roughly similar to Aiguablava spessartites and high-K basalts from Sardinia in most elements. Dotted lines enclose the data from the Catalan Coastal Ranges and Sardinia. Data sources as in Figure 3. 
Other SCLM domains in Western Europe present different $\mathrm{Sr}-\mathrm{Nd}$ isotopic compositions in geochemically similar enriched mafic dykes. In southwest Britain, post-Variscan ultrapotassic lamprophyres emplaced north of a main boundary, fall on the mantle array, with $\varepsilon \mathrm{Nd}_{\mathrm{i}}$ ranging from -1 to +1.6 , related to the Avalonia terrane, while those south of the boundary are enriched in radiogenic $\mathrm{Sr}$, have initial $\varepsilon \mathrm{Nd}_{\mathrm{i}}$ values of -0.3 to +3.5 , and are isotopically indistinguishable from similar-aged lamprophyres in Armorican massifs in Europe (Dijkstra and Hatch, 2018). Lamprophyres from Vosges and Black Forest show even lower $\varepsilon \mathrm{Nd}_{\mathrm{i}}$ values that overlap with LGL between -4 and -6 , as well as the highest ${ }^{87} \mathrm{Sr} /{ }^{86} \mathrm{Sr}_{\mathrm{i}}$ enrichments between 0.708 and 0.712. Soder (2017) found a boundary between Saxo-thuringian granitoids and lamprophyres with higher $\varepsilon \mathrm{Nd}_{\mathrm{i}}$ and lower ${ }^{87} \mathrm{Sr} /{ }^{86} \mathrm{Sr}_{\mathrm{i}}$, and the Moldanubian granitoids and lamprophyres with lower $\varepsilon \mathrm{Nd}_{\mathrm{i}}$ and higher ${ }^{87} \mathrm{Sr} /{ }^{86} \mathrm{Sr}_{\mathrm{i}}$ that cluster together with LGL dykes (Fig. 8B).

\section{$\mathrm{U}-\mathrm{Pb}$ ages in titanite}

The lack of fresh phenocrysts, commonly used for lamprophyre dating, and the scarcity of zircons, make titanite and allanite from the matrix the only minerals suitable for dating. Allanite shows intense alteration and yields lower intercept dates with large uncertainties, therefore only titanite ages are taken into account. Additionally, only small crystals of titanite are present, so that it was not possible to obtain several spots from a single unzoned crystal. Therefore, the ages are an average of several titanite grains of up to $50 \mu \mathrm{m}$ in length. The only reliable ages obtained come from two variably altered dykes. The less altered dyke yielded the best results with lowest Mean Square Weighted Deviation (MSWD $=0.89$ ) and concordia ages from Tera-Wasserburg diagram of $262 \pm 7 \mathrm{Ma}$ (mid to late Permian), while the most altered dyke yielded $255 \pm 17 \mathrm{Ma}$ with $\mathrm{MSWD}=1.7$ (Middle Permian to Middle Triassic; Fig. 9). Raw U-Pb data of titanite is presented in Table 3.

\section{DISCUSSION}

\section{Petrographic classification and alteration}

The similarities between all LGL dykes in terms of color, texture and mineral composition, as well as comparable HFSE, REE and some major-element contents (Figs. 3; 4) suggest that they formed from the same magmatic source. On the other hand, heteromorphism (differences in phenocrysts, microphenocrysts and matrix crystal sizes) coupled with similar chemistry of immobile elements suggests that dykes cooled at different rates and represent discrete low-volume pulses. But in spite of being discrete pulses, similarity in emplacement characteristics (orientation and space-filling features) suggests these pulses are close in time under the same tectonic regime. As secondary or alteration minerals are abundant and completely replace most phenocrysts and part of groundmass crystals, it is difficult to distinguish primary crystal features and evaluate processes of fractional crystallization and magma mixing. Nevertheless, as LGL dykes are similar to Aiguablava's spessartites, the observed fully chloritized phenocrysts probably correspond to clinopyroxene with minor amphibole and olivine, as Aiguablava's. This would explain the moderate $\mathrm{MgO}, \mathrm{Cr}$, and $\mathrm{Ni}$ concentrations, which are common in mantle-derived rocks. The occurrence of chloritized mafic phenocrysts of comparable sizes and shapes in dykes with different cooling rates (Fig. 2A-F), suggests that the phenocrysts did not crystalize during the late stage cooling but may have formed during either previous periods of stagnation or by mixing with another magma carrying these phenocrysts.

The principal criteria of lamprophyre classification is based on the relative abundance of primary mica and amphibole phenocrysts (Le Maitre et al., 2002), which appear chloritized in LGL dykes, and of plagioclase and K-feldespar, which are strongly modified by the alteration. Thus, alteration obliterates the primary composition and blurs the mineralogical classification. Nevertheless, the predominance of amphibole in the matrix, the predominance of primary plagioclase and the calc-alkaline geochemical affinity point towards a classification as spessartites.

TABLE 2. Whole-rock $\mathrm{Sr}$ and $\mathrm{Nd}$ isotopic data of $\mathrm{LGL}$ dykes. Initial ${ }^{87} \mathrm{Sr} /{ }^{86} \mathrm{Sr}$ and $\varepsilon \mathrm{Nd}$ were calculated at $262 \mathrm{Ma}$ using $\lambda^{87} \mathrm{Rb}=1.42 \mathrm{E}^{-11} \mathrm{y}^{-1}$ and $\lambda 147 \mathrm{Sm}=6.54 \mathrm{E}^{-12} \mathrm{y}^{-1},{ }^{147} \mathrm{Sm} /{ }^{144} \mathrm{Nd}_{\mathrm{CHUR}}=0.1967$, and ${ }^{143} \mathrm{Nd} /{ }^{144} \mathrm{Nd}_{\mathrm{CHUR}}=0.512638$, respectively

\begin{tabular}{lrrrrr}
\hline & Dyke 1 & Dyke 2 & Dyke 3 & Dyke 4 & Dyke 5 \\
\hline $\mathrm{Rb}$ & 68 & 51 & 29 & 9 & 47 \\
$\mathrm{Sr}$ & 391 & 295 & 360 & 296 & 349 \\
${ }^{87} \mathrm{Sr} /{ }^{86} \mathrm{Sr}$ & $0.711277 \pm 5$ & $0.710588 \pm 3$ & $0.710924 \pm 4$ & $0.711628 \pm 3$ & $0.710086 \pm 5$ \\
${ }^{87} \mathrm{Sr} /{ }^{86} \mathrm{Sr}$ & 0.709242 & 0.708565 & 0.709982 & 0.711272 & 0.708510 \\
$\mathrm{Sm}$ & 8.58 & 8.32 & 8.9 & 8.22 & 8.09 \\
$\mathrm{Nd}$ & 41.7 & 43.7 & 43.4 & 40.7 & 39.3 \\
${ }^{143} \mathrm{Nd} / 144 \mathrm{Nd}$ & $0.512238 \pm 1$ & $0.512249 \pm 1$ & $0.51224 \pm 1$ & $0.512232 \pm 1$ & $0.512246 \pm 2$ \\
$\varepsilon \mathrm{Nd}$ & -5.18 & -4.63 & -5.14 & -5.23 & -5.04 \\
\hline
\end{tabular}



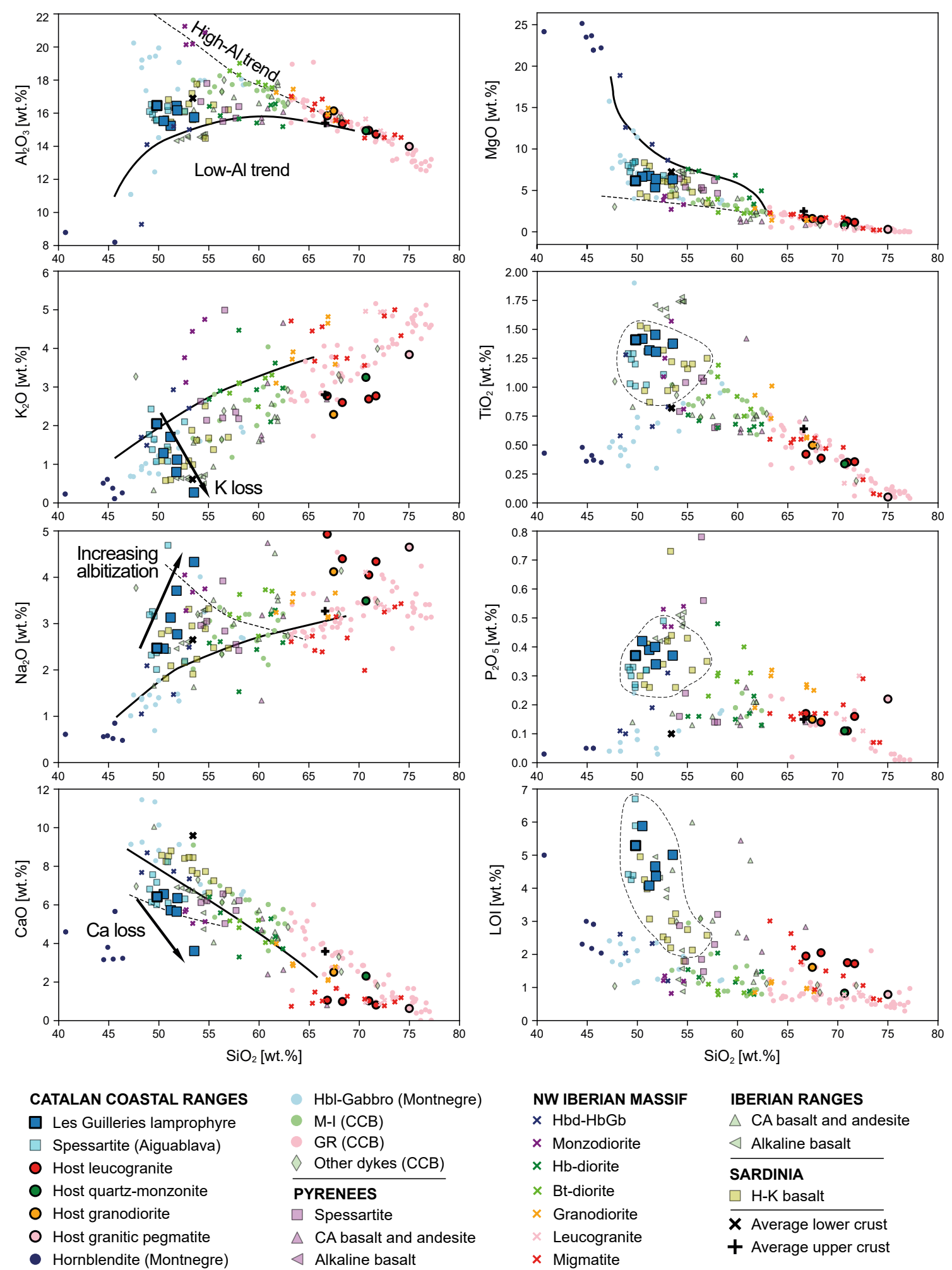
Hbl-Gabbro (Montnegre)
- $M-I(C C B)$
GR (CCB)
$\diamond$ Other dykes (CCB)
PYRENEES
$\square$ Spessartite
$\triangle$ CA basalt and andesite
$\triangleleft$ Alkaline basalt
$\times \mathrm{Hbd}-\mathrm{HbGb}$
$\times$ Monzodiorite
$\times$ Hb-diorite
$\times$ Bt-diorite
$\times$ Granodiorite
- Leucogranite
$\times$ Migmatite

NW IBERIAN MASSIF

IBERIAN RANGES

\begin{tabular}{l}
$\triangle$ CA basalt and andesite \\
$\triangle$ Alkaline basalt \\
\hline SARDINIA \\
$\square$ H-K basalt \\
\hline X Average lower crust \\
+ Average upper crust
\end{tabular}

FIGURE 7. Harker variation diagrams showing LGL dykes major element trends with respect to host granitoids and rocks from the Catalan Coastal Batholith (Enrique, 1990). Comparison with appinite suits of the Sanabria complex in NW Iberia (Castro et al., 2003) is provided. Lines show the main trends defined by Castro et al. (2003): a high-Al trend (dashed line) and a low-Al trend (continuous line). The high-Al trend links monzodiorites and Bt-diorites with tonalites, granodiorites and migmatites. The low-Al trend links Hb-gabbros and Hb-diorites. The two trends converge at silica contents of $63 w \mathrm{w} \%$ for most elements. LGL dykes, Aiguablava spessartites and high-K basalts from Sardinia plot between these two trends, with commonly higher $\mathrm{K}_{2} \mathrm{O}, \mathrm{TiO}_{2}, \mathrm{P}_{2} \mathrm{O}_{5}$ and LOI at the same silica content. Data sources as in Figure 3. M-I: mafic and intermediate igneous rocks. GR: syn to post collisional Variscan granitoids. Hbd-Gabbro: Hornblendite and horndblende gabbros. 
TABLE 3. Titanite U-Pb data of measured ratios corrected for common $\mathrm{Pb}$

\begin{tabular}{|c|c|c|c|c|c|c|c|c|c|c|c|c|}
\hline Sample & ${ }^{207} \mathrm{~Pb} / 235 \mathrm{U}$ & $2 \sigma$ & ${ }^{206} \mathrm{~Pb} / 238 \mathrm{U}$ & $2 \sigma$ & rho & ${ }^{238} \mathrm{U} /{ }^{206} \mathrm{~Pb}$ & $2 \sigma$ & ${ }^{207} \mathrm{~Pb} /{ }^{206} \mathrm{~Pb}$ & $2 \sigma$ & rho & ${ }^{208} \mathrm{~Pb} /{ }^{232} \mathrm{Th}$ & $2 \sigma$ \\
\hline Gl7-Ttn1 & 2.35 & 0.13 & 0.0590 & 0.0018 & 0.73 & 16.95 & 0.53 & 0.2924 & 0.0113 & 0.50 & 0.0272 & 0.0014 \\
\hline GI7-Ttn2 & 6.43 & 0.15 & 0.0907 & 0.0020 & 0.61 & 11.03 & 0.24 & 0.5113 & 0.0116 & 0.56 & 0.1490 & 0.0082 \\
\hline GI7-Ttn3 & 2.91 & 0.35 & 0.0641 & 0.0033 & 0.14 & 15.60 & 0.79 & 0.3260 & 0.0405 & 0.32 & 0.0352 & 0.0038 \\
\hline Gl7-Ttn4 & 5.57 & 0.38 & 0.0880 & 0.0036 & 0.55 & 11.36 & 0.46 & 0.4670 & 0.0286 & 0.48 & 0.0628 & 0.0092 \\
\hline GI7-Ttn5 & 9.39 & 0.80 & 0.1225 & 0.0069 & 0.71 & 8.16 & 0.46 & 0.5380 & 0.0309 & 0.34 & 0.1530 & 0.0911 \\
\hline Gl7-Ttn6 & 13.48 & 0.40 & 0.1502 & 0.0036 & 0.84 & 6.66 & 0.16 & 0.6503 & 0.0153 & 0.47 & 0.2130 & 0.0118 \\
\hline GI7-Ttn7 & 10.87 & 0.96 & 0.1313 & 0.0095 & 0.86 & 7.62 & 0.55 & 0.5980 & 0.0295 & 0.41 & 0.4100 & 0.2801 \\
\hline GI7-Ttn8 & 7.90 & 1.41 & 0.1040 & 0.0102 & 0.90 & 9.62 & 0.94 & 0.5110 & 0.0461 & 0.52 & 0.1270 & 0.0401 \\
\hline Gl7-Ttn9 & 11.72 & 0.75 & 0.1387 & 0.0103 & 0.82 & 7.21 & 0.53 & 0.6050 & 0.0278 & 0.28 & 0.0630 & 0.0121 \\
\hline GI7-Ttn10 & 13.20 & 1.13 & 0.1493 & 0.0096 & 0.95 & 6.70 & 0.43 & 0.6400 & 0.0263 & 0.60 & 0.2040 & 0.0611 \\
\hline GI7-Ttn11 & 13.50 & 1.33 & 0.1530 & 0.0114 & 0.94 & 6.54 & 0.49 & 0.6580 & 0.0239 & 0.53 & 0.3300 & 0.1202 \\
\hline GI7-Ttn12 & 13.98 & 0.69 & 0.1599 & 0.0052 & 0.18 & 6.25 & 0.20 & 0.6240 & 0.0307 & 0.40 & 0.0920 & 0.0102 \\
\hline GI7-Ttn13 & 18.00 & 1.54 & 0.1930 & 0.0126 & 0.96 & 5.18 & 0.34 & 0.6770 & 0.0217 & 0.61 & 0.1830 & 0.0213 \\
\hline GI7-Ttn14 & 8.63 & 0.97 & 0.1136 & 0.0083 & 0.22 & 8.80 & 0.64 & 0.5560 & 0.0808 & 0.38 & 0.1500 & 0.1600 \\
\hline GI7-Ttn15 & 24.75 & 0.53 & 0.2479 & 0.0056 & 0.58 & 4.03 & 0.09 & 0.7254 & 0.0160 & 0.50 & 0.2410 & 0.0129 \\
\hline GI7-Ttn16 & 24.40 & 1.20 & 0.2413 & 0.0110 & 0.92 & 4.14 & 0.19 & 0.7320 & 0.0183 & 0.50 & 0.3510 & 0.0973 \\
\hline GI7-Ttn17 & 23.79 & 0.85 & 0.2406 & 0.0075 & 0.23 & 4.16 & 0.13 & 0.7150 & 0.0262 & 0.52 & 0.2700 & 0.0553 \\
\hline Gl7-Ttn18 & 12.40 & 1.82 & 0.1510 & 0.0133 & 0.56 & 6.62 & 0.59 & 0.5950 & 0.0700 & 0.32 & 0.2730 & 0.0932 \\
\hline GI7-Ttn19 & 26.50 & 2.36 & 0.2610 & 0.0187 & 0.94 & 3.83 & 0.28 & 0.7290 & 0.0325 & 0.25 & 0.2380 & 0.0472 \\
\hline GI7-Ttn20 & 34.30 & 1.38 & 0.3340 & 0.0155 & 0.91 & 2.99 & 0.14 & 0.7500 & 0.0192 & 0.44 & 0.6300 & 0.1804 \\
\hline GI7-Ttn21 & 35.70 & 1.94 & 0.3410 & 0.0156 & 0.95 & 2.93 & 0.13 & 0.7510 & 0.0180 & 0.43 & 0.2900 & 0.0306 \\
\hline GI7-Ttn22 & 32.50 & 4.15 & 0.3150 & 0.0326 & 0.99 & 3.17 & 0.33 & 0.7450 & 0.0266 & 0.63 & 0.1200 & 0.0113 \\
\hline GI7-Ttn23 & 35.20 & 1.57 & 0.3350 & 0.0129 & 0.94 & 2.99 & 0.11 & 0.7630 & 0.0188 & 0.32 & 0.3150 & 0.0258 \\
\hline GI7-Ttn24 & 38.20 & 1.77 & 0.3600 & 0.0157 & 0.98 & 2.78 & 0.12 & 0.7652 & 0.0169 & 0.55 & 0.3950 & 0.0575 \\
\hline GI7-Ttn25 & 36.00 & 8.83 & 0.3240 & 0.0653 & 1.00 & 3.09 & 0.62 & 0.7420 & 0.0265 & 0.36 & 0.2590 & 0.0453 \\
\hline GI7-Ttn26 & 41.20 & 3.01 & 0.3790 & 0.0252 & 0.98 & 2.64 & 0.18 & 0.7860 & 0.0198 & 0.32 & 0.5000 & 1.0000 \\
\hline GI7-Ttn27 & 45.59 & 1.03 & 0.4266 & 0.0097 & 0.90 & 2.34 & 0.05 & 0.7773 & 0.0163 & 0.36 & 0.5990 & 0.0398 \\
\hline GI7-Ttn28 & 45.70 & 1.59 & 0.4260 & 0.0147 & 0.94 & 2.35 & 0.08 & 0.7776 & 0.0172 & 0.40 & 0.1629 & 0.0054 \\
\hline GI7-Ttn29 & 45.50 & 1.67 & 0.4260 & 0.0147 & 0.95 & 2.35 & 0.08 & 0.7810 & 0.0174 & 0.32 & 0.2319 & 0.0085 \\
\hline GI7-Ttn30 & 43.30 & 7.55 & 0.4040 & 0.0635 & 1.00 & 2.48 & 0.39 & 0.7740 & 0.0253 & 0.59 & 0.7300 & 0.3703 \\
\hline GI7-Ttn31 & 47.20 & 2.58 & 0.4360 & 0.0227 & 0.95 & 2.29 & 0.12 & 0.7828 & 0.0178 & 0.60 & 0.2014 & 0.0099 \\
\hline Gl7-Ttn32 & 47.60 & 2.68 & 0.4430 & 0.0219 & 0.95 & 2.26 & 0.11 & 0.7770 & 0.0203 & 0.43 & 0.4130 & 0.0645 \\
\hline GI7-Ttn33 & 52.90 & 5.50 & 0.4820 & 0.0509 & 0.99 & 2.07 & 0.22 & 0.8019 & 0.0186 & 0.18 & 0.7000 & 0.2204 \\
\hline GI7-Ttn34 & 54.10 & 2.10 & 0.5020 & 0.0189 & 0.88 & 1.99 & 0.07 & 0.7810 & 0.0185 & 0.28 & 0.6950 & 0.0871 \\
\hline GI7-Ttn35 & 53.40 & 8.17 & 0.4920 & 0.0677 & 0.99 & 2.03 & 0.28 & 0.7900 & 0.0240 & 0.61 & 0.7700 & 0.4902 \\
\hline GI7-Ttn36 & 64.10 & 4.11 & 0.5740 & 0.0407 & 0.93 & 1.74 & 0.12 & 0.8120 & 0.0265 & 0.39 & 0.7400 & 0.2804 \\
\hline GI7-Ttn37 & 70.20 & 2.13 & 0.6300 & 0.0188 & 0.95 & 1.59 & 0.05 & 0.8128 & 0.0172 & 0.31 & 0.5780 & 0.0397 \\
\hline GI7-Ttn38 & 71.10 & 3.78 & 0.6280 & 0.0316 & 0.97 & 1.59 & 0.08 & 0.8179 & 0.0186 & 0.57 & 0.5900 & 0.3402 \\
\hline GI7-Ttn39 & 89.80 & 2.69 & 0.8090 & 0.0228 & 0.96 & 1.24 & 0.03 & 0.8087 & 0.0170 & 0.30 & 1.3500 & 0.1820 \\
\hline GI7-Ttn40 & 94.80 & 4.61 & 0.8380 & 0.0452 & 0.96 & 1.19 & 0.06 & 0.8120 & 0.0196 & 0.48 & 1.4000 & 1.3003 \\
\hline
\end{tabular}


The replacement of primary magmatic phases by secondary minerals typical of greenschist-facies metamorphism (calcite, chlorite and epidote) is a ubiquitous feature in many lamprophyres (Rock, 1991). This is sometimes understood as autometasomatic processes upon solidification of melts with high volatile content (Rock, 1991). In LGL dykes the calcite-chloriteepidote paragenesis occurs together with albite and hematite (Fig. 3H). Moreover, there is a systematic variation in $\mathrm{Na}_{2} \mathrm{O}, \mathrm{SiO}_{2}, \mathrm{~K}_{2} \mathrm{O}, \mathrm{CaO}, \mathrm{F}, \mathrm{Ba}, \mathrm{Rb}, \mathrm{Cs}, \mathrm{Pb}, \mathrm{Sr}$ and $\mathrm{Zn}$ (Fig. 5) with the abundance of albite, chlorite, hematite, titanite, and their replacement textures (Fig. 2). Similar precipitation of minute hematite crystals and albitization of plagioclases have been observed in late-Variscan granitoids of the extended Montseny-Guilleries Massif (Fàbrega et al., 2019), Paleozoic rocks of the Variscan Morvan Massif in France (Parcerisa et al., 2010) and host granitoids from this study. Therefore, one or more post-magmatic processes of alteration must have affected LGL dykes additionally to common autometasomatic processes. The anomalously low concentration of $\mathrm{K}_{2} \mathrm{O}$ and $\mathrm{K}_{2} \mathrm{O} / \mathrm{Na}_{2} \mathrm{O}$ ratios in LGL dykes with respect to lamprophyres from other massifs (Fig. 3C), seem to occur also in Aiguablava spessartites, according to the published geochemical data (Enrique, 2009; Ubide et al., 2010), which suggests albitization was a common process across the CCR in contrast to other Variscan domains. Recent studies have suggested that an albitization event developed under low-temperature subsurface conditions previous to erosion that led to the Lower Triassic paleosurface (Fàbrega et al., 2019; Parcerisa et al., 2010). Additionally, the elements that may have been remobilized by the albitization ( $\mathrm{Ba}, \mathrm{F}, \mathrm{Pb}, \mathrm{Zn}$ ) in Les Guilleries are concentrated in epigenetic vein mineralizations nearby (Osor fluorite-barite-sphalerite-galena veins). As this mineral deposit is related to hydrothermal fluid circulation, the same hydrothermal event could have been responsible for the alteration of LGL dykes, although it is still not clear if there is a direct relationship between the lamprophyres and fluorite deposits.

\section{Age of emplacement}

From field observations, LGL dykes are younger than all late-Variscan syn-post collisional plutons of Les Guilleries and nearby massifs with ages ranging from $323.6 \pm 2.8 \mathrm{Ma}$

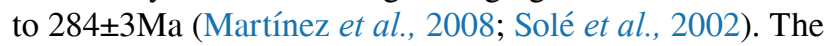
new U-Pb titanite MSDW age of $262 \pm 7 \mathrm{Ma}$ is in agreement with the crosscutting relationships, although this age may be skewed towards younger ages due to the influence of secondary titanite related with post-magmatic alteration. Additionally, late crystallization and post magmatic events are known to yield up to $19 \mathrm{Myr}$ younger $\mathrm{U}-\mathrm{Pb}$ ages in titanite than early crystallizing zircons in Variscan granites (Broska and Petrík, 2013). This suggests that LGL dyke emplacement may be slightly older than matrix titanite crystallization at $262 \pm 7 \mathrm{Ma}$, but younger than the most felsic magmatism. An approximate E-W orientation of LGL dykes with gentle N-dipping and emplacement along fractures and diaclases are similar to what is observed in Aiguablava's spessartites intruded in ca. 288Ma pluton, and considering the geochemical similarities, both dyke swarms may have resulted from related events.

\section{Relation with appinite suites of the Catalan Coastal Batholith}

The REE parallel profiles of LGL dykes and their host rocks (Fig. 4B) suggest they have a common source and are related by fractionation processes (e.g. Fowler and Henney, 1996), which is common of appinite suites (Murphy, 2013). Indeed, the Catalonian Coastal Batholith plutonic and hypabyssal association forms a very complete post-collisional calc-alkaline igneous suite (Enrique, 1990; Martínez et al., 2008; Figure 7). The suite's ultrabasicbasic to intermediate rocks, with olivine hornblendites, hornblende melanogabbros-gabbros and leucogabbros, are associated with late-Variscan calc-alkaline granites in the Susqueda complex and Montnegre Massif, that have been interpreted as appinite suites (Butjosa et al., 2013; Galán et al., 2017). The most acidic rocks of the suite are hornblendebiotite quartz diorites and monzodiorites. Although the evolutionary trend of this association is calc-alkaline, the hornblendites and the leucogabbros are thought to be derived from basic magmas enriched in $\mathrm{K}$, whereas quartz diorites are considered hybrid rocks, generated by mixing of basic and felsic magmas (Butjosa et al., 2013). The mineralogical and geochemical characteristics of LGL dykes match those of the hypothesized basic parental magmas of the appinite suite, an amphibole-phlogopite-bearing melt with high potassium and high fluid content (Fig. 7). Therefore, the LGL dykes probably represent the least modified magmas from the SCLM beneath the CCR during Variscan times to reach crustal levels, along lithospheric-scale deep transcurrent faults, and could represent one of the deepest sources of heat and material of the Variscan-post-collisional magmatism. The lamprophyre magmas could have transferred fluids as well as LILE (K, Ba, Rb, Cs, Pb, Th), HFSE (Ti, P, Zr, Nb) and REE from the metasomatized lithospheric mantle to the crust, and thus probably played a significant role in crustal melting and formation of mineral resources.

The relationship between appinites and calc-alkaline lamprophyres has long been recognized (Rock, 1991). Examples of hornblendites related to granitoids and/ or migmatites exist in the Iberian Massif, Pyrenees and other Variscan terranes in the context of large scale dextral strike-slip tectonics produced by the interaction between Laurassia and Gondwana, and coeval lamprophyre dykes are present in all this places (Bea et al., 1999; Castro et al., 2003; Roberts et al., 2000; Scarrow et al., 2009). 


\section{Source characteristics and melting conditions}

The $\mathrm{Th} / \mathrm{Yb}$ vs. $\mathrm{Nb} / \mathrm{Yb}$ ratios (Fig. 10A) are usually interpreted to reflect source composition and/or crustal assimilation (Pearce et al., 2008), where subduction processes and crustal contamination usually result in an enrichment of $\mathrm{Th}$ with respect to $\mathrm{Nb}$. The significantly high $\mathrm{Th} / \mathrm{Yb}$ ratio for the most basic LGL sample, with $49.82 \% \mathrm{SiO}_{2}$, is unlikely to be explained only by crustal contamination, and probably reflects the extent of metasomatism during Variscan and/or older subduction events in the SCLM source. This is also consistent with $\mathrm{Sr}-\mathrm{Nd}$ isotopic variations reflecting an enriched lithospheric mantle source with high ${ }^{87} \mathrm{Sr} /{ }^{86} \mathrm{Sr}_{\mathrm{i}}$ and low
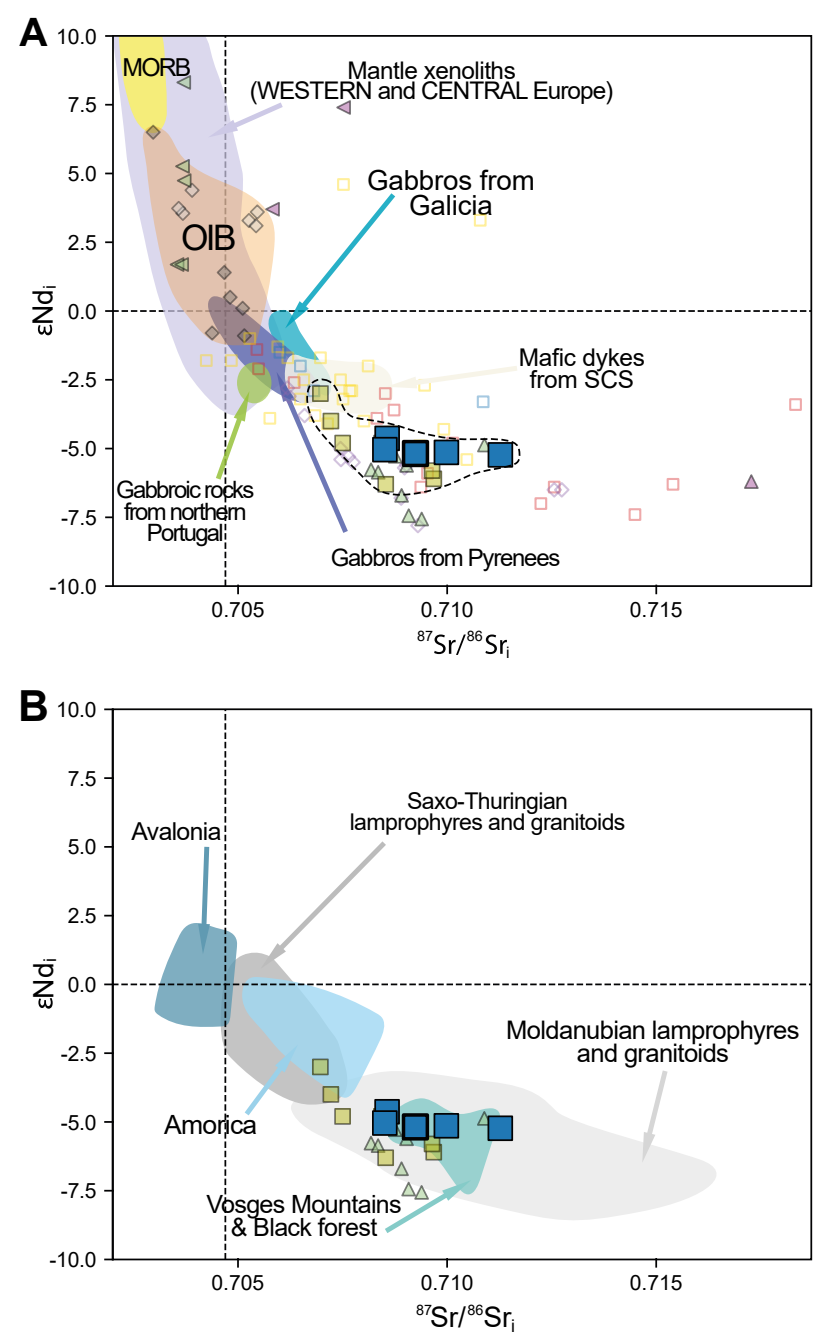

FIGURE 8. Initial Sr-Nd isotopic compositions of LGL dykes at 262Ma. Isotopic compositions of post-collisional A) Variscan mafic rocks and previously defined B) Variscan SCLM domains are shown for comparison. Dashed lines represent Bulk Earth isotopic ratios from DePaolo (1980). Data sources as in Figure 3 except for Avalonia and Amorica Massifs that are from Dijkastra and Hatch (2018) and references therein. Saxo-thuringian and Moldanubian domains in $B$ are from Soder (2017). Note that LGL dykes cluster with high-K basalts from Sardinia and Permian andesites from the Iberian Ranges, suggesting a common SCLM source. $\varepsilon \mathrm{Nd}_{\mathrm{i}}$ (Fig. 8), although mixing with small proportions of crustal magmas or fluids cannot be discarded, as deduced by the presence of xenocrysts and hybridization textures. Ratios between $\mathrm{Rb}, \mathrm{Ba}$ and $\mathrm{Sr}$ are commonly used to discriminate phlogopite vs. amphibole rich sources, which is not possible for LGL dykes as those elements have been remobilized by post-magmatic processes. However, the predominance of amphibole over phlogopite in most mafic lithologies is a common feature of appinite rocks from the CCR. Additionally, the ratios between LREE and HREE in LGL dykes could be explained by an amphibole lherzolite mantle source with a combination of spinel and garnet as aluminum phases. This is observed in the diagram of Figure 10B, C, where garnet-compatible $\mathrm{Yb}$ is compared with $\mathrm{La}, \mathrm{Sm}$ and Gd-garnet incompatible elements (Rollinson, 1993). Additionally, the Sm/Yb vs. La/Sm diagram (Fig. 10C; Jung et al., 2006) also shows that a spinel and garnet lherzolite around $2 \%$ degree of melting could explain the observed ratios.

Integrating the above results, major, trace- and rare-earth-element ratios suggest that the LGL magma source was probably an enriched SCLM with the composition of an amphibole-bearing spinel-garnet lherzolite that underwent low degrees of partial melting. Similar sources have been proposed for post-collisional spessartites across the Variscan Belt in the Bohemian Massif, Vosges and Black Forest (Soder, 2017). However, lamprophyre dyke swarms related to the inner parts of the orogenic belt show a wide variety of lamprophyre types with higher LILE, HSFE, REE enrichments (Fig. $3 ; 6)$, being the most extreme examples the lamproites and peralkaline minnetes from the Bohemian Massif and Black Forest, respectively, that formed from very low degree melting of enriched domains (Krmíček et al., 2015; Soder, 2017), not observed in the CCR. Figure 11 shows there is a compositional continuum between high-K lamproites and low-K gabbros revealing different degrees of metasomatism in Variscan SCLM, variable melting conditions and complex differentiation stories. LGL dykes and high-K basaltic andesitic dykes from Sardinia represent moderately enriched SCLM in LILE, HFSE and REE closer to lower crustal values in most elements than most enriched species of the inner Variscan belt (Figs. 3; 6;11). Although there is still few isotopic data to define precise lithospheric domains, the striking geochemical similarities between CCR and Sardinia's mafic dykes with respect to dykes from other Variscan domains strongly suggest they come from a similar and compositionally unique domain of the Variscan SCLM, different from other parts of the Variscan Belt of western Europe. However, it is still not clear whether these geochemical features are related to the nature and source of the subducted continental material and/or conditions of partial melting and the nature of residual phases. 


\section{REGIONAL CORRELATIONS}

Post-collisional magmatism in NE Iberia happened several tens of million years after the main Variscan tectono-metamorphic event related to the Rheic suture in the Inner Variscan Belt, during Late Devonian to Early Carboniferous (Wilson et al., 2004). Most calc-alkaline lamprophyre dykes in the Inner Variscan belt are older than LGL dykes, with ages that range from Early Carboniferous to Early Permian (Seifert, 2008; Soder, 2017). However, calc-alkaline lamprophyre dykes with younger Permian ages and geochemistry similar to the one of LGL dykes are also

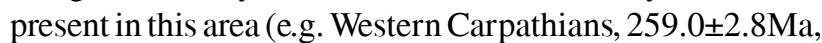
spessartites, Spišiak et al., 2019; Bohemian massif, kersantites and spessartites, Seifert, 2008). This suggests that these Mid to Late Permian calc-alkaline lamprophyres occurred in domains with similar characteristics with respect to the architecture of the Variscan Belt under a strike-slip regime previous to the extensional post-orogenic regime (Debon and Zimmermann, 1993).

The age obtained in this study is also similar to a RbSr biotite age of $259 \pm 3 \mathrm{Ma}$ from a calc-alkaline basaltic andesite dyke from the Sarrabus batholith in Sardinia, where mafic dykes cross cut 290 to 270Ma metaluminous and peraluminous rhyolitic products. This age points to some mafic magmatism intruding after the felsic magmatism (Ronca et al., 1999), similar to what is observed in the CCR. This age also indicates that the change from a calcalkaline (orogenic) to an alkaline (anorogenic) signature in post-collisional magmatism, related to the transition from the first to the second cycle as defined by Cortesogno et al. (1998), did not occur before $262 \pm 7$ Ma in the CCR.
Such change from orogenic calc-alkaline to anorogenic alkaline magmatism is also present in lamprophyre dykes from the western Pyrenees (Debon and Zimmermann, 1993) and Sardinia (Bonin, 1987), as well as in volcanic rocks from Permian pull-apart basins of the Iberian Ranges and eastern Pyrenees, which occurred from Early Permian to Late Permian-Triassic (Arche and López-Gómez, 1996; Innocent et al., 1994). In summary, the calc-alkaline signature of LGL dykes represent the latest stage in the evolution from Early Permian strike-slip tectonics (associated or not with a Paleotethys subduction environment, Pereira et al., 2014; Perini et al., 2004) to Late Permian extension associated with the Neotethys opening.

\section{CONCLUSIONS}

Les Guilleries lamprophyre dykes constitute a mostly vertical dyke swarm that intrudes late Carboniferous to early Permian granitoids and lower Paleozoic metasediments of the Catalan Coastal Ranges.

The predominance of mafic phenocrysts, porphyritic texture, high $\mathrm{MgO}$ and volatile content, together with crustal-like trace-element patterns indicate that LGL dykes correspond to calc-alkaline lamprophyres, probably spessartites. The parallel REE pattern of lamprophyres and host rocks indicates a common magmatic source.

The geochemical characteristics of LGL dykes (enrichments in LILE, HFSE and REE) is a feature shared with the calc-alkaline lamprophyres from the CCR
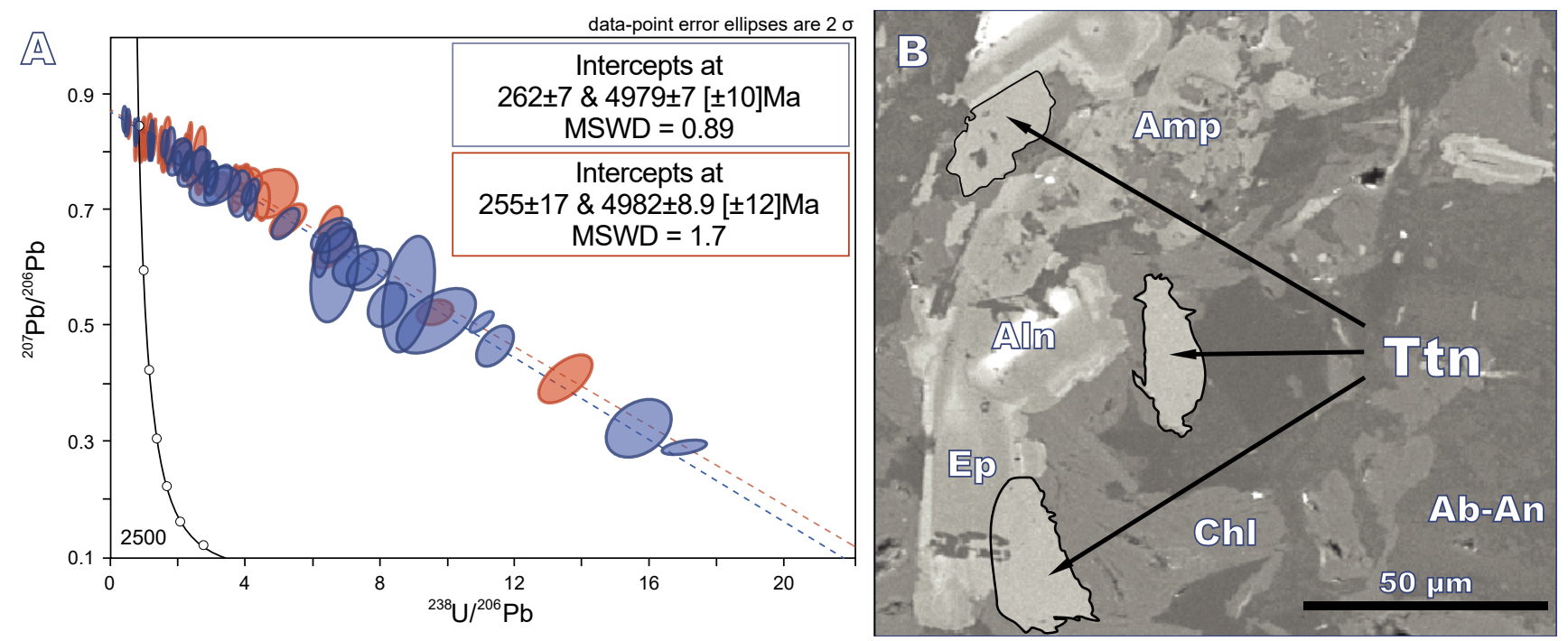

FIGURE 9. A) Titanite Tera-Wasserburg concordia diagram using measured ${ }^{207} \mathrm{~Pb} / 206 \mathrm{~Pb}$ and ${ }^{238} \mathrm{U} /{ }^{206} \mathrm{~Pb}$ ratios corrected for common $\mathrm{Pb}$, with the data conversion performed by Isoplot 3.7. Titanite data from the two samples are plotted at $2 \sigma$ and uncertainties on lower intercept ages are $95 \%$ confidence. B) BSE images showing examples of analyzed titanite crystals. 

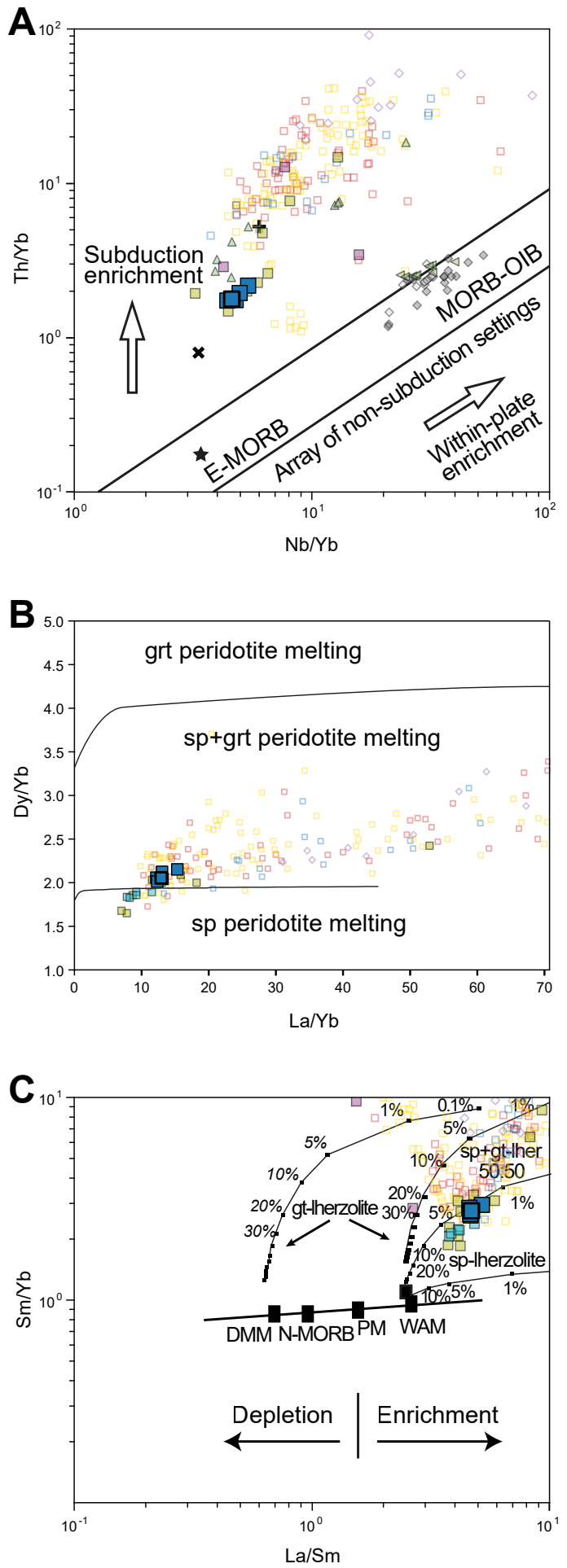

FIGURE 10. A) Nb/Yb vs. Th/Yb plot (after Pearce, 2008) suggesting LGL mantle source enrichement from subduction episodes. B) La/ $\mathrm{Yb}$ vs. Dy/Yb plot suggesting LGL generation at shallow depth in spinel+garnet-peridotite stability field near the boundary of pure spinel-peridotite stability field (after Jung et al., 2006). C) La/Sm vs. $\mathrm{Sm} / \mathrm{Yb}$ plot showing partial melting curves for a spinel-Iherzolite and a garnet-Iherzolite (Aldanmaz et al. (2000) and references therein) mantle. REE ratios of LGL dykes fit the field around $2 \%$ degree of melting in a spinel+garnet Iherzolite at 50:50 proportion. DMM: Depleted Mantle. PM: Primitive Mantle. WAM: Western Anatolian Mantle. Data sources and symbols as in Figure 3.
(Aiguablava) and high K-basalts from Sardinia, as well as Permian calc-alkaline andesites from the eastern Pyrenees and Iberian Ranges.

High ${ }^{87} \mathrm{Sr} /{ }^{86} \mathrm{Sr}$ and low ${ }^{143} \mathrm{Nd} /{ }^{144} \mathrm{Nd}$ isotope ratios suggest an enriched subcontinental lithospheric mantle source similar to what is found in post-collisional K-rich mafic dykes from Sardinia, Permian calc-alkaline andesites from Iberian Ranges and other defined Variscan terranes like the Moldanubian domain.

The intrusion of LGL dykes occurred during Permian times, as reflected in the $\mathrm{U}-\mathrm{Pb}$ ages of matrix titanite crystals that yield concordia ages of 262 \pm 7 Ma. Mafic rocks from Sardinia have similar age and probably shared a similar SCLM.

The emplacement of LGL dykes was controlled by secondary faults of the main NW-SE strike-slip dextral system that emplaced the granitoids during the postcollisional evolution. Thermal relaxing and lithospheric thinning after the Variscan continental collision allowed the emplacement of mantle-derived magmas at upper crustal levels in small volume short-lived magmatic pulses.

Post-magmatic processes of chloritization and albitization affected the lamprophyres causing the systematic variations of $\mathrm{Na}_{2} \mathrm{O}, \mathrm{SiO}_{2}, \mathrm{~K}_{2} \mathrm{O}, \mathrm{CaO}, \mathrm{F}, \mathrm{Ba}, \mathrm{Rb}$, $\mathrm{Cs}, \mathrm{Pb}, \mathrm{Sr}, \mathrm{Tl}$, and $\mathrm{Zn}$. They are also shared with granitoid host rocks, so that albitization must be unrelated to magmatic processes and may have occurred during early Triassic times, by comparison with other albitized rocks of the Catalan Variscan domain.

The calc-alkaline signature of LGL dykes marks them as the latest Variscan magmatism event, which is related to the Early Permian strike-slip tectonics, before the Late Permian extension associated with the Neotethys opening and anorogenic alkaline magmatism.

\section{ACKNOWLEDGMENTS}

This manuscript forms part of the first author's $\mathrm{PhD}$ thesis, undertaken at the Universitat Autònoma de Barcelona. Financial support for this project was provided by the Spanish Ministerio de Economía, Industria y Competitividad, projects CGL2015-66335-C2-2-R and PID2019-109018RB-I00 and by the Comisión Nacional de Investigación Científica y Tecnológica, project "CONICYT PFCHA/DOCTORADO BECAS CHILE/2017-72180523”. We thank Francisco Martínez, Esteve Cardellach and Isaac Corral for their constructive comments, as well as the reviewers and editors which helped to improve this manuscript. 

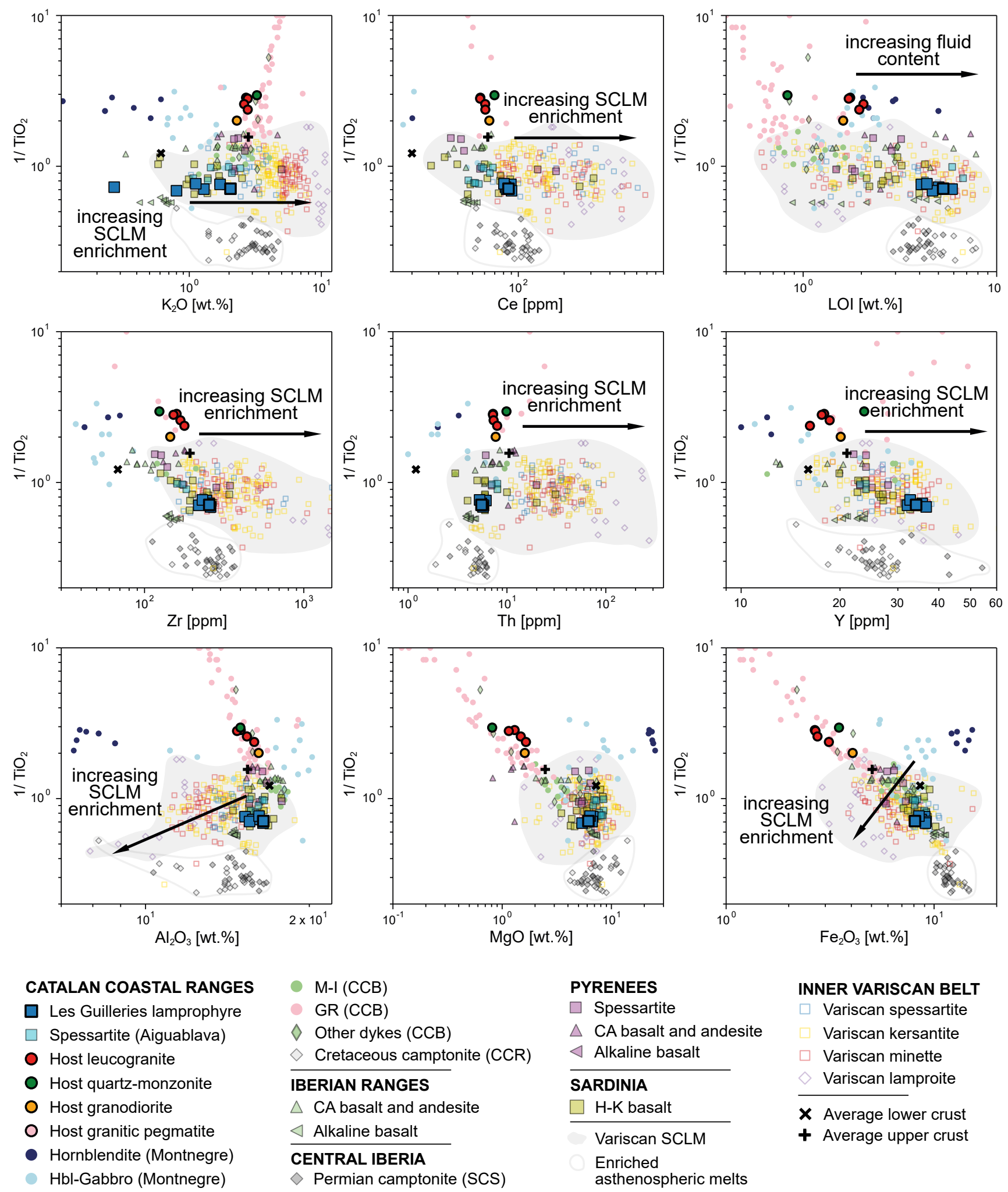

PYRENEES

$\square$ Spessartite

$\triangle$ CA basalt and andesite

$\triangleleft$ Alkaline basalt

\section{SARDINIA}

$\square \mathrm{H}-\mathrm{K}$ basalt

Variscan SCLM

Enriched

asthenospheric melts
INNER VARISCAN BELT

$\square$ Variscan spessartite

Variscan kersantite

$\square$ Variscan minette

Variscan lamproite

X Average lower crust

+ Average upper crust

FIGURE 11. Plots of $1 / \mathrm{TiO}_{2}$ vs. various elements showing major compositional end-members of Variscan magmatism in the Catalan Coastal Ranges and adjacent Paleozoic massifs. Calc-alkaline lamprophyres and lamproites define heterogeneous SCML enrichment in different parts of Western Europe, while alkaline lamprophyres represent the influence of enriched asthenospheric OIB melts in the SCML. Note that LGL dykes are compositionally similar to Aiguablava spessartites and high-K basalts from Sardinia in most elements. Data sources as in Figure 3. 


\section{REFERENCES}

Aldanmaz, E., Pearce, J., Thirlwall, M., Mitchell, J.G., 2000. Petrogenetic evolution of late Cenozoic, post-collision volcanism in western Anatolia, Turkey. Journal of Volcanology and Geothermal Research, 102, 67-95.

Arche, A., López-Gómez, J., 1996. Origin of the Permian-Triassic Iberian Basin, central-eastern Spain. Tectonophysics, 266, 443-464.

Awdankiewicz, M., 2007. Late Paleozoic lamprophyres and associated mafic subvolcanic rocks of the Sudetes (SW Poland): petrology, geochemistry and petrogenesis. Geologia Sudetica, 39, 11-97.

Ayora, C., Soler, A., Melgarejo, J.C., 1990. The Hercynian ore deposits from the Catalonian Coastal Ranges. Acta Geologica Hispanica, 25, 65-73.

Bea, F., Montero, P., Molina, J.F., 1999. Mafic precursors, peraluminous granitoids, and late lamprophyres in the Avila batholith: A model for the generation of Variscan batholiths in Iberia. Journal of Geology, 107, 399-419.

Bonin, B., 1987. From orogenic to anorogenic magmatism: a petrological model for the transition calc-alkaline-alkaline complexes. Revista Brasileira de Geociencias, 17(4), 366-371.

Broska, I., Petrík, I., 2014. Accessory phases in the genesis of the igneous rocks. In: Kumar, S., Singh, R.N. (eds.). Modelling of Magmatic and Allied Processes, 109-149. DOI: 10.1007/9783-319-06471-0_6

Bussy, F, Hernandez, J., Von Raumer, J., 2000. Bimodal magmatism as a consequence of the post-collisional readjustment of the thickened Variscan continental lithosphere (Aiguilles RougesMont Blanc Massifs, Western Alps). Earth and Environmental Science Transactions of the Royal Society of Edinburgh, 91(12), 221-233.

Butjosa, L., Enrique, P., Galán, G., 2013. Las hornblenditas, gabros y dioritas del Macizo del Montnegre (Barcelona, Cordilleras Costero Catalanas). Geogaceta, 54, 35-38.

Campá-Viñeta, J.A., Montoriol-Pous, J., 1974. Mineralogénesis del yacimiento de Osor (Gerona). Acta Geologica Hispanica, 4, 139-141.

Castro, A., Corretgé, L.G., de la Rosa, J.D., Fernández, C., López, S., García-Moreno, O., Chacón, H., 2003. The appinitemigmatite complex of Sanabria, NW Iberian Massif, Spain. Journal of Petrology, 44, 1309-1344.

Cortesogno, L., Cassinis, G., Dallagiovanna, G., Gaggero, L., Oggiano, G., Ronchi, A., Seno, S., Vanossi, M., 1998. The Variscan post-collisional volcanism in Late Carboniferous Permian sequences of Ligurian Alps, Southern Alps and Sardinia (Italy): a synthesis. Lithos, 45(1), 305-328.

Debon, F, Zimmermann, J.L., 1993. Mafic dykes from some plutons of the Western Pyrenean Axial Zone (France, Spain): markers of the transition from Late-Hercynian to early Alpine events. Schweizerische Mineralogische und Petrographische Mitteilungen, 73, 421-433.

DePaolo, D.J., 1980. Crustal growth and mantle evolution: inferences from models of element transport and $\mathrm{Nd}$ and
Sr isotopes. Geochimica et Cosmochimica Acta, 44(8), 1185-1196.

Dijkstra, A.H., Hatch, C., 2018. Mapping a hidden terrane boundary in the mantle lithosphere with lamprophyres. Nature Communications, 9, 1-8. DOI: 10.1038/s41467-018-06253-7

Durán, H., 1985. El Paleozóico de les Guilleries. Doctoral Thesis. Bellaterra (Spain), Universitat Autònoma de Barcelona, 243pp.

Durán, H., 1990. El Paleozoico de les Guilleries. Acta Geologica Hispanica, 25, 83-103.

Elter, FM., Corsi, B., Cricca, P., Muzio, G., 2004. The southwestern Alpine foreland: correlation between two sectors of the Variscan chain belonging to 'stable Europe': Sardinia (-) Corsica and the Maures Massif (south-eastern France). Geodinamica Acta, 17, 31-40.

Enrique, P., 1990. The Hercynian intrusive rocks of the Catalonian Coastal Ranges (NE Spain). Acta Geologica Hispanica, 25, 39-64.

Enrique, P., 2009. Las espesartitas, camptonitas y bostonitas del complejo intrusivo de Aiguablava (Cadenas Costeras Catalanas): Cartografía y composición. Geogaceta, 47, 125-128.

Esteve, S., Sunyer, J., Culí, L., Cirés, J., Alías, G., 2016. El complejo intrusivo diorítico-gabroico de Susqueda (Macizo del Montseny-Guilleries, Cataluña): unidades litológicas y características petrográficas. Geogaceta, 60, 99-102.

Esteve, S., Enrique, P., Alías, G., 2018. Relaciones intrusivas y cronología relativa del plutón básico de Susqueda con las rocas metamórficas encajantes (Cordillera Prelitoral Catalana). Geogaceta, 63, 107-110.

Fàbrega, C., Parcerisa, D., Thiry, M., Franke, C., Gurenko, A., Gómez-Gras, D., Solé, J., Travé, A., 2019. Permian-Triassic red-stained albitized profiles in the granitic basement of NE Spain: evidence for deep alteration related to the Triassic paleosurface. International Journal of Earth Sciences, 108, 2325-2347.

Foley, S.F., 1992. Vein-plus-wall-rock melting mechanisms in the lithosphere and the origin of potassic alkaline magmas. Lithos, 28, 435-453.

Fowler, M.B., Henney, PJ., 1996. Mixed Caledonian appinite magmas: implications for lamprophyre fractionation and high Ba-Sr granite genesis. Contributions to Mineralogy and Petrology, 126, 199-215.

Galán, G., Enrique, P., Butjosa, L., Fernández-Roig, M., 2017. Spinels of Variscan olivine hornblendites related to the Montnegre granitoids revisited (NE Spain): petrogenetic evidence of mafic magma mixing. Geologica Acta, 15(4), 323-336.

Innocent, C., Briqueu, L., Cabanis, B., 1994. Sr-Nd isotope and trace-element geochemistry of late Variscan volcanism in the Pyrenees: Magmatism in post-orogenic extension? Tectonophysics, 238, 161-181.

Jung, C., Jung, S., Hoffer, E., Berndt, J., 2006. Petrogenesis of Tertiary mafic alkaline magmas in the Hocheifel, Germany. Journal of Petrology, 47, 1637-1671. 
Krmíček, L., Romer, R., Ulrych, J., Glodny, J., Prelević, D., 2015. Petrogenesis of orogenic lamproites of the Bohemian Massif: $\mathrm{Sr}-\mathrm{Nd}-\mathrm{Pb}-\mathrm{Li}$ isotope constraints for Variscan enrichment of ultra-depleted mantle. Gondwana Research, 35, 198-216.

Lago, M., Arranz, E., Pocoví, A., Galé, C., Gil-Imaz, A., 2004. Permian magmatism and basin dynamics in the Southern Pyrenees: a record of transition from late Variscan transtension to early Alpine extension. In: Wilson, M., Neumann, E.-R., Davies, G.R., Timmerman, M.J., Heeremans, M., Larsen, B.T. (eds.). Permo- Carboniferous magmatism and rifting in Europe. London, Geological Society, 223 (Special Publications), 439-464.

Lago, M., de la Horra, R., Ubide., T., Galé., C., Galán-Abellán., B., Barrenechea., J.F., López-Gómez., J., Benito., M.I., Arche., A., Alonso-Azcárate, J., Luque., FJ., Timmerman., M.J., 2012. First report of a Middle-Upper Permian magmatism in the SE Iberian Ranges: characterisation and comparison with coeval magmatisms in the western Tethys. Journal of Iberian Geology, 38(2), 331-348.

Losantos, M., Montaner, J., Solà, J., Mató, E., Sampsó, J.M., Picart, J., Calvet, F, Enrique, P., Ferrés, M., Solé, J., 2000. Mapa Geològic de Catalunya 1:25.000. Palafrugell 335-1-1 (79-25). Barcelona, Servei Geològic de Catalunya (ICC).

le Maitre, R., Streckeisen, A., Zanettin, B., Le Bas, M., Bonin, B., Bateman, P. (eds.), 2002. Igneous Rocks: A Classification and Glossary of Terms: Recommendations of the International Union of Geological Sciences Subcommission on the Systematics of Igneous Rocks (2nd ed.). Cambridge, Cambridge University Press, 19. DOI: 10.1017/ CBO9780511535581

Martínez, FJ., Reche, J., Iriondo, A., 2008. U-Pb SHRIMP-RG zircon ages of Variscan igneous rocks from the Guilleries massif (NE Iberia pre-Mesozoic basement): Geological implications. Comptes Rendus Geoscience, 340, 223-232.

Martínez, FJ., Iriondo, A., Dietsch, C., Aleinikoff, J.N., Peucat, J.J., Cirés, J., Reche, J., Capdevila, R., 2011. U-Pb SHRIMP$\mathrm{RG}$ zircon ages and Nd signature of Lower Paleozoic riftingrelated magmatism in the Variscan basement of the eastern Pyrenees. Lithos, 127, 10-23.

Martínez-Poza, A.I., Druguet, E., Castaño, L.M., Carreras, J., 2014. Dyke intrusion into a pre-existing joint network: The Aiguablava lamprophyre dyke swarm (Catalan Coastal Ranges). Tectonophysics, 630, 75-90.

McDonough, W.F, Sun, S.S., 1995. The composition of the Earth. Chemical Geology, 120, 223-253.

Murphy, J., 2013. Appinite suites: A record of the role of water in the genesis, transport, emplacement and crystallization of magma. Earth-Science Reviews, 119,35-59.

Orejana, D., Villaseca, C., Paterson, B.A., 2006. Geochemistry of pyroxenitic and hornblenditic xenoliths in alkaline lamprophyres from the Spanish Central System. Lithos, 86, 167-196.

Orejana, D., Villaseca, C., Billström, K., Paterson, B.A., 2008. Petrogenesis of Permian alkaline lamprophyres and diabases from the Spanish Central System and their geodynamic context within western Europe. Contributions to Mineralogy and Petrology, 156, 477-500.

Parcerisa, D., Thiry, M., Schmitt, J.M., 2010. Albitisation related to the Triassic unconformity in igneous rocks of the Morvan Massif (France). International Journal of Earth Sciences, 99, 527-544.

Pearce, J., 2008. Geochemical fingerprinting of oceanic basalts with applications to ophiolite classification and the search for Archean oceanic crust. Lithos, 100, 14-48.

Peccerillo, A., Taylor, S.R., 1976. Geochemistry of Eocene calcalkaline volcanic rocks from the Kastamonu area, northern Turkey. Contributions to Mineralogy and Petrology, 58, 63-81.

Peng, P., Ernst, R., Hou, G., Söderlund, U., Zhang, S.H., Hamilton, M., Xu, Y.G., Denyszyn, S., Mège, D., Pisarevsky, S., Srivastava, R., Kusky, T., 2016. Dyke swarms: keys to paleogeographic reconstructions. Science Bulletin, 61(21), 1669-1671. DOI: 10.1007/s11434-016-1184-x

Pereira, M.F., Castro, A., Chichorro, M., Fernández, C., DíazAlvarado, J., Martí, J., Rodríguez, C., 2014. Chronological link between deep-seated processes in magma chambers and eruptions: Permo-Carboniferous magmatism in the core of Pangaea (Southern Pyrenees). Gondwana Research, 25, 290-308.

Perini, G., Cebria, J.M., López-Ruiz, J., Doblas, M., 2004. Carboniferous-Permian mafic magmatism in the Variscan belt of Spain and France: implications for mantle sources. London, Geological Society, 223 (Special Publications), 415-438.

Prelević, D., Foley, S.F., Cvetkovic, V., Romer, R.L., 2004. Origin of Minette by Mixing of Lamproite and Dacite Magmas in Veliki Majdan, Serbia. Journal of Petrology, 45(4), 759-792.

Reche, J., Martínez, FJ., 2002. Evolution of bulk composition, mineralogy, strain style and fluid flow during an HT-LP metamorphic event: sillimanite zone of the Catalan Coastal Ranges, Variscan basement, NE Iberia. Tectonophysics, 348, 111-134.

Riesco, M., Stüwe, K., Reche, J., Martínez, FJ., 2004. Silica depleted melting of pelites. Petrogenetic grid and application to the Susqueda Aureole, Spain. Journal of Metamorphic Geology, 22, 475-494.

Roberts, M., Pin, C., Clemens, J., Paquette, J.L., 2000. Petrogenesis of Mafic to Felsic Plutonic Rock Associations: the Calcalkaline Querigut Complex, French Pyrenees. Journal of Petrology, 41(6), 809-844.

Rock, N.M.S., 1991. Lamprophyres. London, Blackie, 285pp.

Rollinson, H., 1993. Using geochemical data: Evaluation, presentation, interpretation. New York, Longman Scientific and Technical, Wiley, 352.

Ronca, S., Del Moro, A., Traversa, G., 1999. Geochronology, Sr$\mathrm{Nd}$ isotope geochemistry and petrology of Late-Hercynian dyke magmatism from Sarrabus (SE Sardinia). Periodico di Mineralogia, 68, 231-260.

Rudnick, R.L., Gao, S., 2003. Composition of the continental crust. In: Rudnick, R.L. (ed.). The Crust. Treatise on Geochemistry, Oxford, Elsevier, 3, 1-64. 
Scarrow, J.H., Molina, J.F, Bea, F. Montero, P., 2009. Within-plate calc-alkaline rocks: Insights from alkaline mafic magmasperaluminous crustal melt hybrid appinites of the Central Iberian Variscan continental collision. Lithos, 110, 50-64.

Sebastian, A., Reche, J., Duran, H., 1990. Hercynian metamorphism in the Catalonian coastal ranges. Acta Geologica Hispanica, 255, 31-32.

Seifert, T., 2008. Metallogeny and Petrogenesis of Lamprophyres in the Mid-European Variscides. Amsterdam, IOS Press, 303.

Soder, C., 2017. Geochemistry and petrology of lamprophyres from the Hellenides and the European Variscides. PhD Thesis. Heidelberg (Germany), University of Heidelberg, 201pp. DOI: 10.11588/heidok.00023679

Solé, J., Cosca, M., Sharp, Z., Enrique, P., 2002. 40Ar/39Ar Geochronology and stable isotope geochemistry of LateHercynian intrusions from north-eastern Iberia with implications for argon loss in K-feldspar. International Journal of Earth Sciences, 91, 865-881.

Spišiak, J., Vetráková, L., Mikuš, T., Chew, D., Ferenc, S., Šimonová, V., Siman, P., 2019. Mineralogy and geochronology of calc-alkaline lamprophyres from the Nízke Tatry Mts. Crystalline complex (Western Carpathians). Mineralia Slovaca, 51, 61-78.

Srivastava, R., Ernst, R., Peng, P., 2019. Dyke Swarms of the World: A Modern Perspective. Singapore, Springer, 263-314. DOI: $10.1007 / 978-981-13-1666$
Sun, S.S., McDonough, W.F, 1989. Chemical and isotopic systematics of oceanic basalts: implications for mantle composition and processes. London, Geological Society, 42 (Special Publications), 313-345.

Tanaka, T., Togashi, S., Kamioka, H., Amakawa, H., Kagami, H., Hamamoto, T., Yuhara, M., Orihashi, Y., Yoneda, S., Shimizu, H., Kunimaru, T., Takahashi, K., Yanagi, T., Nakano, T., Fujimaki, H., Shinjo, R., Asahara, Y., Tanimizu, M., Dragusanu, C., 2000. JNdi-1: a neodymium isotopic reference in consistency with La Jolla neodymium. Chemical Geology, $168,279-281$

Ubide, T., Lago, M., Arranz, E., Galé, C., Larrea, P., 2010. The lamprophyric sub-vertical dyke swarm from Aiguablava (Catalonian Coastal Ranges): Petrology and composition. Geogaceta, 49, 83-86.

Ubide, T., 2013. The Cretaceous alkaline magmatism in northeast Iberia: igneous processes and geodynamic implications. Doctoral Thesis. Zaragoza (Spain), University of Zaragoza, 193pp.

Wilson, M., Neumann, E.R., Davies, G., Timmerman, M., Heeremans, M., Larsen, B., 2004. Permo-Carboniferous Magmatism and Rifting in Europe. London, Geological Society, 223 (Special Publications), 1-10. DOI: 10.1144/GSL. SP.2004.223.01.01

Winchester, J.A., Floyd, P.A., 1977. Geochemical discrimination of different magma series and their differentiation products using immobile elements. Chemical Geology, 20, 325-343.

Manuscript received March 2021;

revision accepted April 2021;

published Online December 2021. 